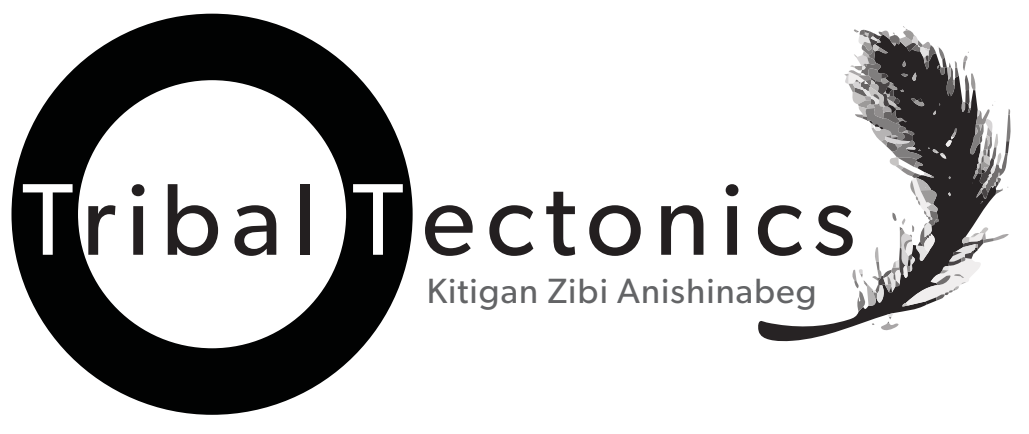




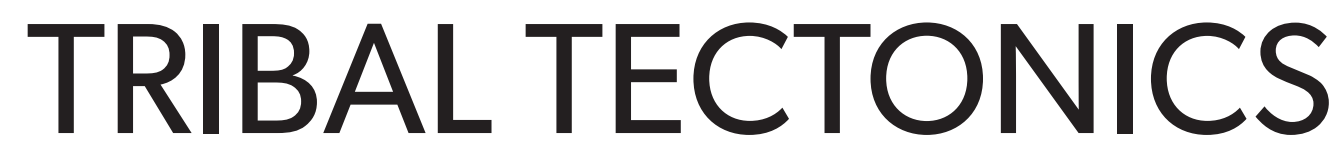

An Architecture of Cultural and Economic development in First Nations Communities

BY

\section{Stéphane Bolduc}

A thesis submitted to the Faculty of Graduate and Postdoctoral Affairs

in partial fulfillment of the requirements for the degree of

Master of Architecture

(M.Arch)

Carleton University

Ottawa, Ontario

(c) 2013

Stéphane Bolduc 


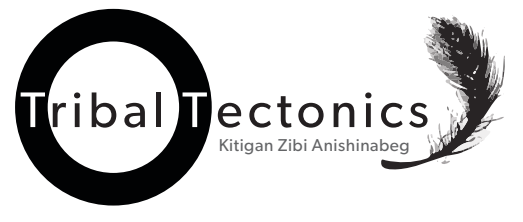

TRIBAL TECTONICS: An Architecture of Cultural and Economic development in First-Nations Communities

Carleton University ID: 100732093

Every reasonable attempt has been made to identify owners of copyright and intellectual property.

Printed in Ottawa, Canada 
Abstract

\section{ABSTRACT}

First Nations peoples, native to the vast and diverse landscape we call Canada, have been forced to adapt to a modernized framework largely crafted by settlers of European descent. A slowly improving relationship between the Canadian government and Aboriginal peoples creates opportunities for a better future, and a better Canada. Many Aboriginal communities across the country are emerging as leaders of tomorrow, yet despite these positive signs of progress, many First Nations communities are still struggling to adapt. Architecture has strong potential to help improve lives, providing hope for a prosperous future; free of poverty, and rich in cultural integrity. The bond between architect and client forms the basis for design work to flourish in a manner which pertains to the specific needs of the community. It is through this reciprocal dialogue that answers may be uncovered, by which meaningful architecture can be realized. 


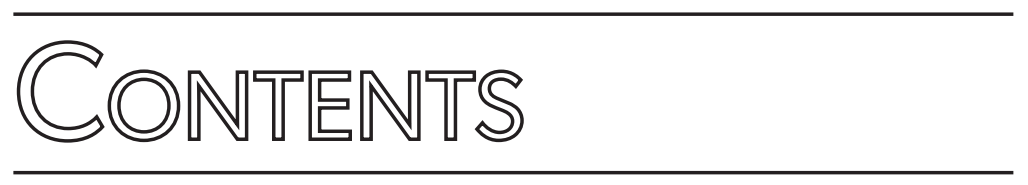

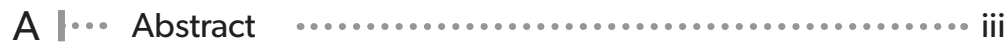

$0 \ldots \ldots$ Then and Now $\ldots \ldots \ldots \ldots \ldots \ldots \ldots \ldots \ldots \ldots \ldots \ldots \ldots \ldots \ldots \ldots \ldots \ldots \ldots$

$1 \ldots \ldots$ First Nations and the Canadian fabric ......... 6

2......................... 10

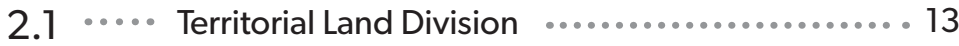

$2.2 \ldots \ldots$ Kitigan Zibi: Current Context $\ldots \ldots \ldots \ldots \ldots \ldots$

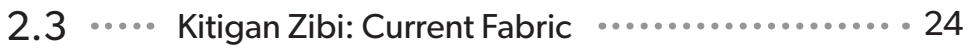

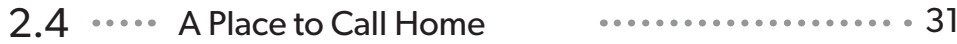

$2.5 \ldots . . . . \ldots . \ldots 37$

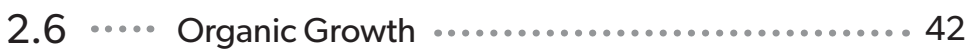

$3 \ldots . . .$. Kitigan Zibi Community Recreation Centre ........ 45

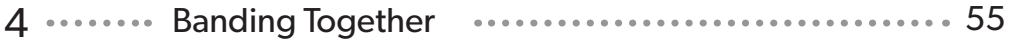

B $\mid \ldots$ Acknoledgements $\ldots \ldots \ldots \ldots \ldots \ldots \ldots \ldots \ldots \ldots \ldots \ldots$ vi

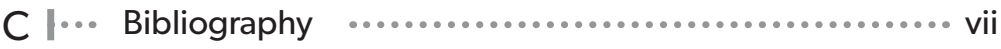

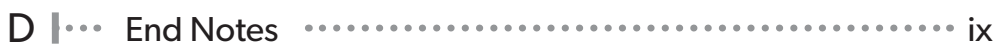

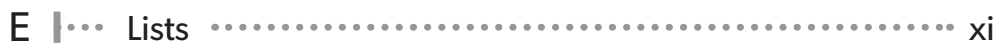


During your read, you will encounter various symbols and graphic notations. Information can be found primarily within the left-hand side bar, but will from time to time find its way scattered throughout the text.

$\square$ IMAGES (SQUARE WITH DIRECTIONAL ARROW)

Used to reference images or graphics

throughout the text.

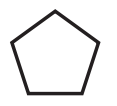

PEOPLE (PENTAGON)

Used to reference descriptions of notable people throughout the text.<smiles>C1CC2CCCC2C1</smiles>

PLACES (STAR)

Used to reference descriptions of notable places throughout the text.

QUOTES (CIRCLE)

Used to reference quotes not found within the thesis text.

ELABORATIONS (NOTCHED SQUARE)

Used to define or elaborate on certain terms or provide additional information on a given subjet. 


\section{(0) THEN \& Now}

Since the arrival of European settlers, Indigenous nations have coexisted with peoples historically foreign to their native land. As a result, Canadian Aboriginal architecture as it exists today is deeply rooted in notions of colonization and missionizing. Pre-colonization, First Nations peoples lived in an ecologically sensible manner, closely tied to the land they dwelled. Understanding that their survival was highly dependent on the health of the ecosystem in which they were a part of, they practiced conservational approaches to the resources they consumed. Tied to notions of mutuality and respect for natural resources, they in turn maintained a reciprocal relationship with their surroundings. In Algonquin bands, territory was divided amongst families for hunting, fishing and trapping. These divisions were often bounded by distinct natural landmarks such as rivers, lakes or land formations. These zones were essentially a family's key to survival. Although the act of hunting on another family's territory was particularly frowned upon, permission to hunt on neighbouring land was often given in times of need. ${ }^{1}$ Travelling and transportation of goods between these areas was mainly done by foot or by canoe. The combination of land and water based travel made undertakings such as hunting, trapping and fishing wholly practical. River systems acted as natural thoroughfares, increasing the viability of nomadic livelihood, thus making water-front dwelling an attractive choice. Coupled with conservative resource management, these activities sustained families for thousands of years. This philosophy starkly contrasts the westernized society we are all currently part of, where the disposability of consumerism plagues our ecological wellbeing. Consequentially, the modern age has rendered the utility of these traditional aboriginal practices obsolete. Methods that have sustained populations for ages exist today, mainly as activities of sport or leisure. This is essentially since the feasibility to sustain large population on hunting and fishing

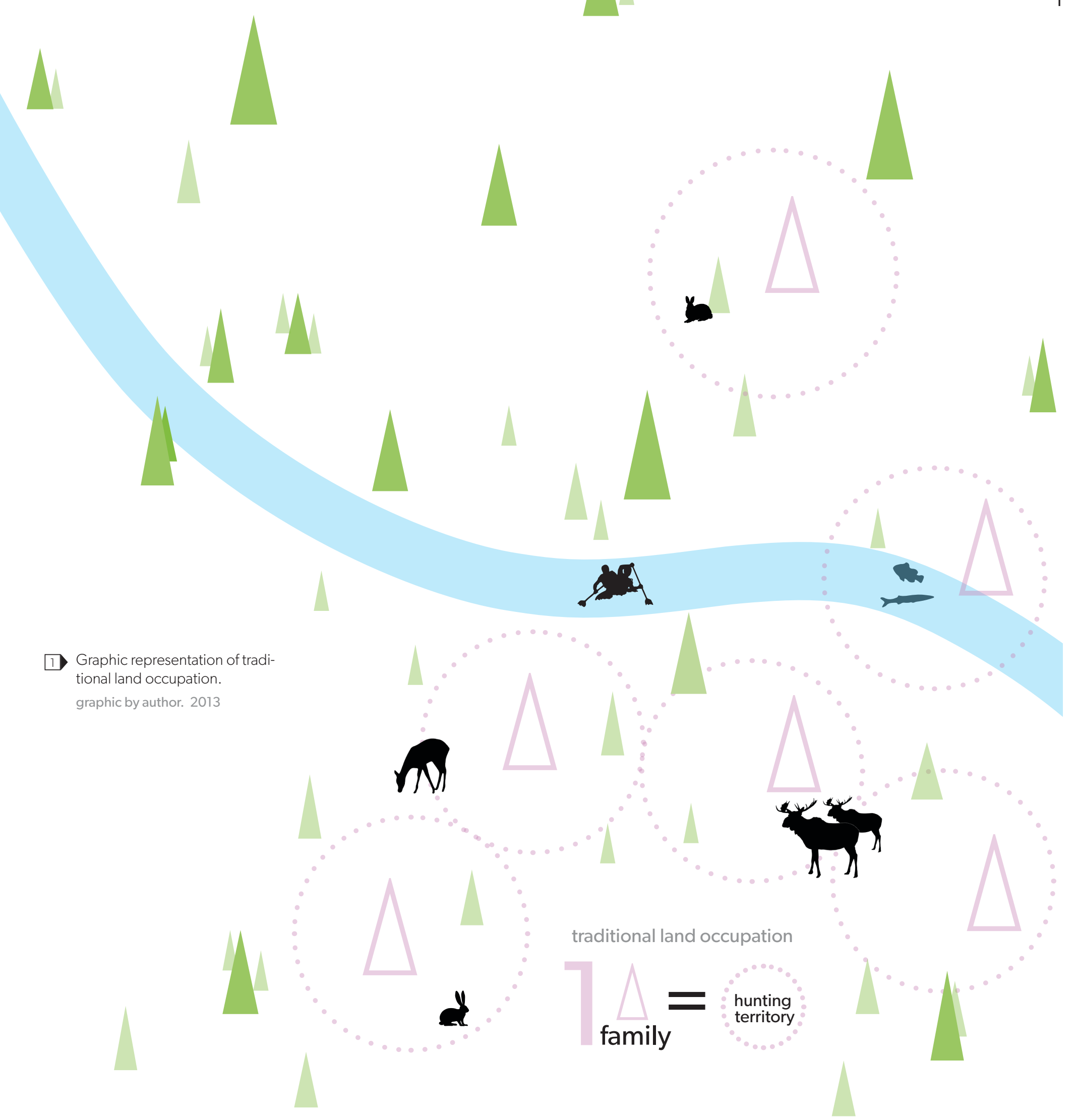


is both impractical and unsustainable in today's present conditions.

The shift of Aboriginal communities into a modernized European framework has inevitably affected the socio-economic and cultural dynamics of their civilization. In the pre-colonial era, domestic animal farming was non-existent in North American geography, primarily due to the lack of livestock. Notions of domestic farming, which were imported from European settlers, meant that communities were becoming more sedentary, settling near sources of food for cultivation. Colonizers also introduced logging practices, accompanied by large expanses of roads, which opened up more Native territory to European immigrants. Many rivers were consequently used for log shipment, thus increasing waterway congestion and reducing the mobility of Aboriginal populations. These environments made it all the more difficult to practice traditional activities, subsequently eroding the traditional territorial system, which revolved around hunting and gathering. ${ }^{2}$ First Nations communities now live in a framework largely governed by descendants of European origins. Many still reside on reserve lands allocated to them by the government, while others have urbanized, living in cities around the country searching for new opportunities to thrive in these present conditions. Some reserves are thriving despite the restricting circumstances they have been placed in but most still live in substandard environments. Many assurances made to them as compensation for wrong-doings well over a century ago, still remain unfulfilled by the Cana- 
Then and Now

Douglas Cardinal

Architect credited with pioneering an indigenous Canadian style of architecture. Drawing from his Blackfoot Indian heritage, he has always been deeply influenced by nature and his surroundings. His trademark free-form shapes and organic designs are exemplified in his best-known work, the Canadian Museum of Civilization in Gatineau, Que.

Brian Maracle. Our Native Land. CBC radio. http://www.cbc.ca/archives/ categories/arts-entertainment/architecture/architecture-general/douglas-cardinals-brand-of-native-architecture.html . 1984/09/29

\section{Oujé-Bougoumou}

Small Aboriginal community in Northern Québec with an unfortunate history of abuse, neglect and dispossession, from mining and forestry companies, as well as governments at both the provincial and federal levels. Living conditions on-reserve were often compared to some of the worst amongst third world countries. After generations of wrongdoings, in May 1992, the community finally received assistance, securing funds from the federal government to build the Oujé-Bougoumou Cree Village. This development consisted of a complete rebuild and redesign of the entire community.

In The Past. http://www.ouje. $\mathrm{ca} /$ content/our-story/history. php. retrieved 2013/03/27 dian government. Essentials, such as education, still continue to be heavily underfunded on reserve land. Schools located on-reserve often receive government funding of $\$ 2000-3000$ less per student, per year, compared to educational facilities off-reserve. ${ }^{3}$

This deplorable state of affairs amassed over centuries has also significantly eroded the architectural and civil dynamics of First Nations around the country and has only recently begun to make a re-emergence. Notable architect, Douglas Cardinal, has dedicated much of his career to stimulating the growth and prosperity in Aboriginal nations through his architecture. One of his most recently acclaimed design accomplishments is the revitalization of the Oujé-Bougoumou Cree village in Northern Quebec. As explained by Douglas Cardinal, the community has had to injure a long history of adversity prior to the redevelopment. "They were abandoned on a lake with nothing. They were living in tarpaper shacks. They were entirely raped of their resources and history." (Douglas Cardinal, 2012) The design process to revitalize

\section{I/ Yes, we have all this great technology, but what are we going to do with it? We're destroying all life on this planet. We're so disconnected from our environment and resources. "I}

- Douglas Cardinal (2012)

Maria Cook. "Douglas Cardinal says a life surrounded by just concrete and people can be devastating." The Ottawa Citizen . 25 February 2012 


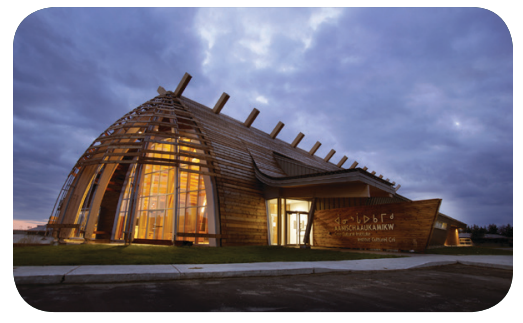

Photo depicting South-West view of the Cree Cultural Institute, located in Oujé-Bougoumou, QC. Building designed by architect Douglas Cardinal

Cree Cultural Institute. http://www. creeculturalinstitute. Oujé-Bougoumou, QC. ca/wp-content/gallery/ media-en/XOC4071.jpg . retrieved 2012/12/18

$4 \mathbb{M A P}$

OUJÉ-BOUGOUMOU VILLAGE

Oujé-Bougoumou Tourism. http:// www.ouje.ca/downloads/ouje-map-business-directory.pdf. retrieved 2013/03/26 the Oujé-Bougoumou revolved around a steady dialogue between himself and community members. ${ }^{4}$ From the discourse between both parties rose an architecture that is both reflective of their heritage, alluding to the prospect of future prosperity. Many other First Nations communities can, and should benefit from the same positive outcome seen in Oujé-Bougoumou. This re-emergence of communal affluence stems from the client-architect discourse, driven by reciprocity and re-enforced by willfulness to impart positive change to be enjoyed by generations to come.

The following will be a discussion of issues concerning the Canadian Aboriginal population as a whole, but more specifically of a an Aboriginal community named Kitigan Zibi Anishinabeg, located north of Ottawa next to the town of Maniwaki. I was first introduced to Kitigan Zibi as part of a research team hired to document existing infrastructural conditions on reserve. After several months detailing the reserve's infrastructural fabric, I met numerous community members, all sharing

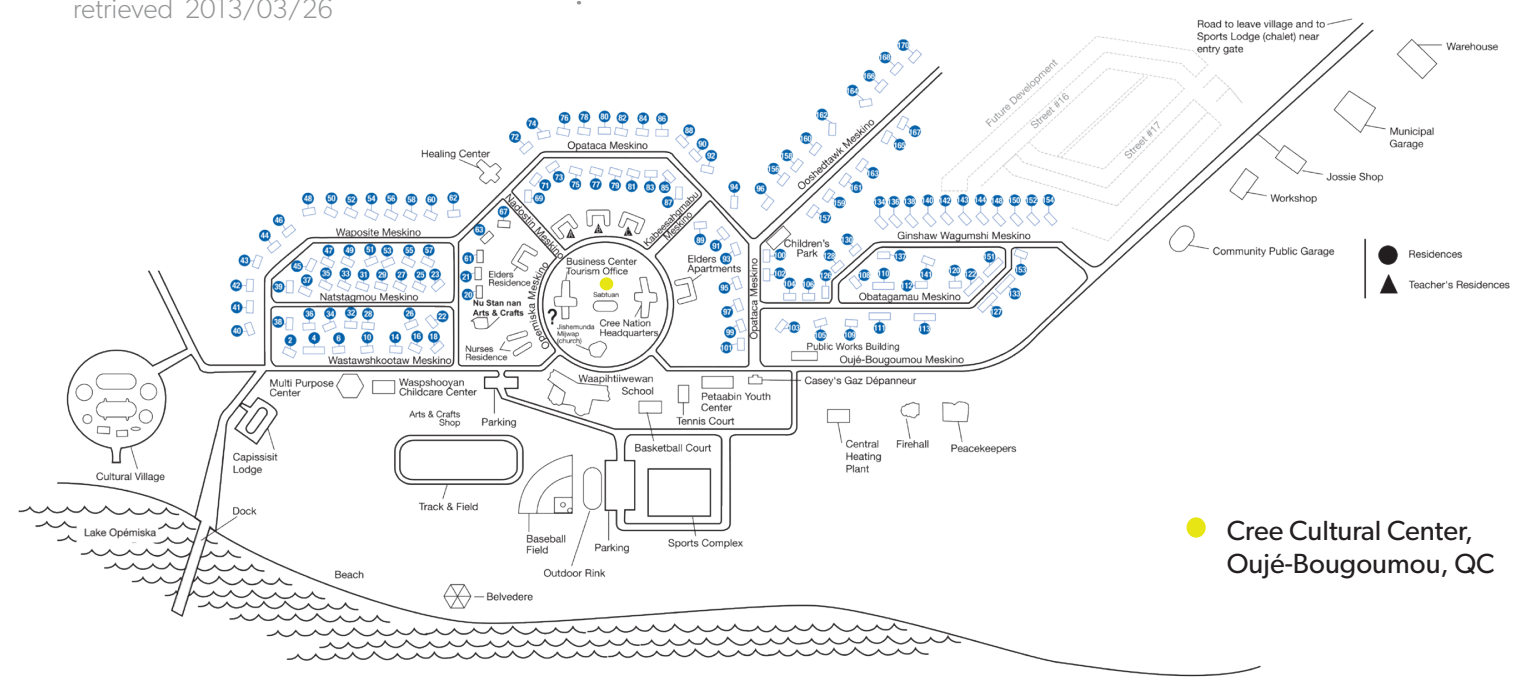




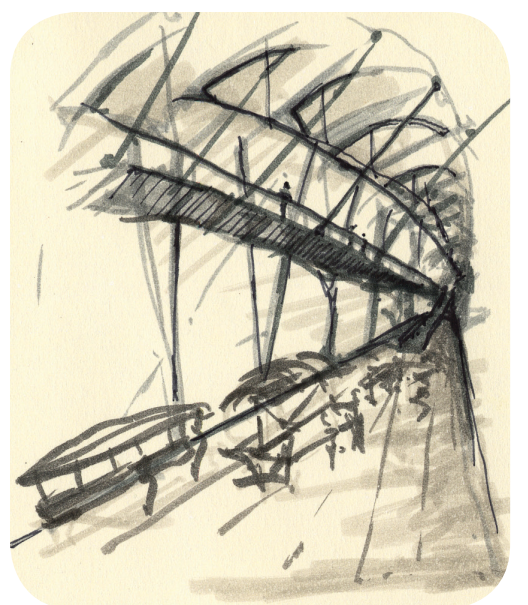

Early design sketch of an indoor marketplace, following a conversation with members of the Kitigan Zibi community.

Sketch by author. 2013/01/10 insight as to what it meant to be a part of Kitigan Zibi. Over this short time period I discovered many wonderful aspects about the community, along with the struggles they've encountered along the way. Being responsible only for the documentation of current natural and built conditions, I offered to provide additional assistance to formulate strategies for future development on reserve. From then began an open dialogue enabling me to discover and learn about the community's rich cultural history, as well as their aspirations for the future. It also exposed many issues affecting their current infrastructural development and economic framework, which formed the basis for architectural discussions. Together we began to form notions from converging ideological pathways, inspiring sketches and design considerations. Through these symbiotic philosophies, this collaborative engine of ideas began to generate new tangential treads of information, eventually leading to potential solutions. The enthusiasm and excitement of the Kitigan Zibi community fueled the creative process, infusing the architectural language with their own unique cultural character. In a conversation with Douglas Cardinal, he declared that in order to meet the needs of the people, "you must become a facilitator", bringing their vision to the forefront of the design process. ${ }^{5}$ It is from this basis that I emphasise, in order to conceive architecture which acutely responds to the specific needs of a community, ideas must be channeled through a reciprocal dialogue between architect, client and community members. 


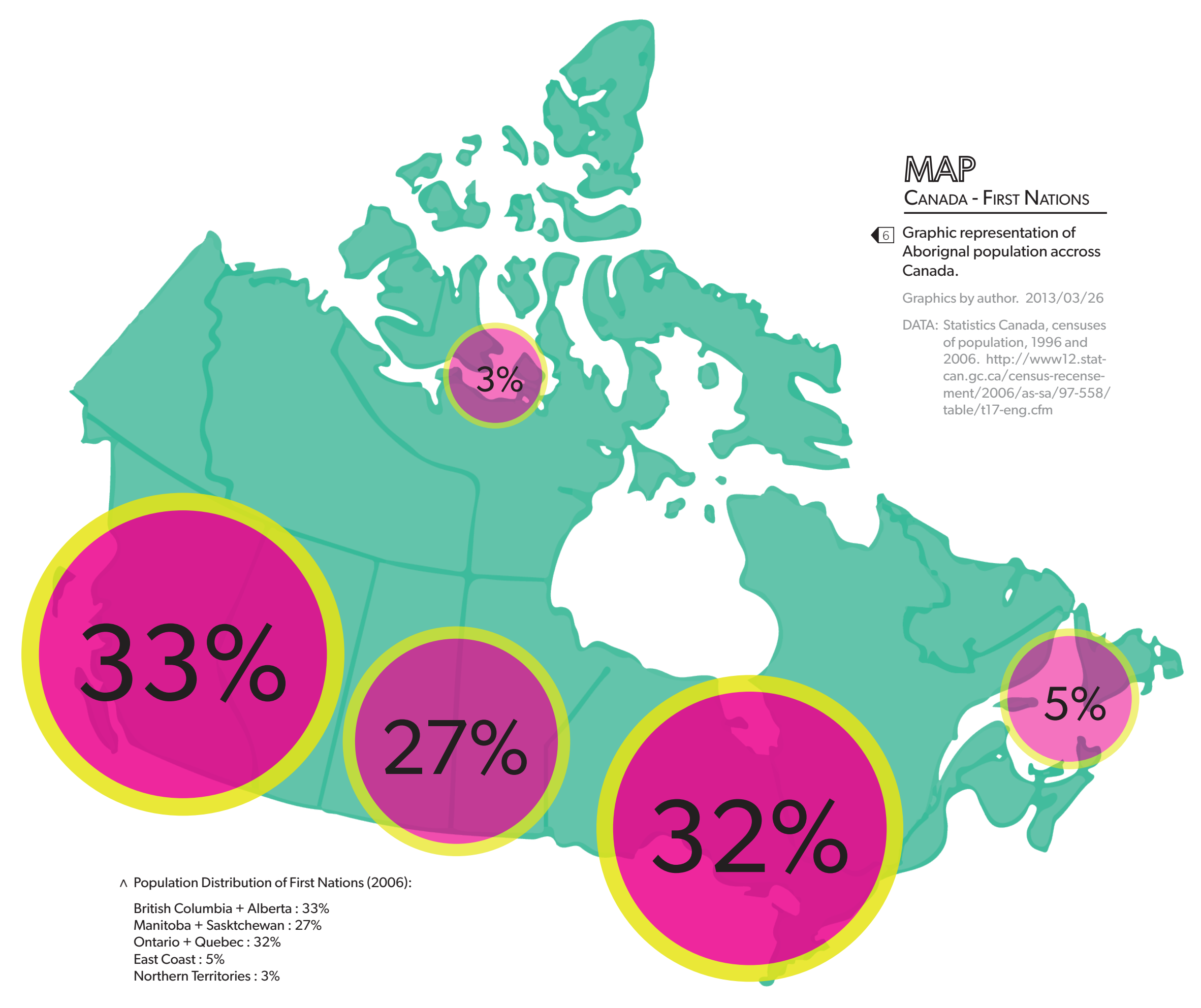

$T_{\text {he Aboriginal population stretches to every corner of }}$ the Canadian landscape consisting of many different nations. Amassed, is a population of roughly 700000 inhabitants, and nearly 1200000 when combining First Nations, Métis and Inuit. ${ }^{6}$ This is indeed a substantial portion of Canadian citizens, which have an extraordinary impact on our future as a country. Of these nearly 1200000 inhabitants, only $44 \%$ reside on reserve land leaving $56 \%$ of the Indigenous population now living off-reserve, predominantly in urban areas. The urban center currentIy hosting the largest population of First-Nations is Winnipeg, Manitoba, with roughly 63000 Aboriginal citizens in 2006. ${ }^{7}$ When considering the fact that on-reserve communities are significantly underfunded when compared other Canadian locales, it begins to suggest that many flee to cities seeking equal opportunity. Could this be an indicator that Aboriginals feel the need to migrate to urban locations due to disadvantaged conditions, caused by underfunding? Or is it simply that many believe they can find better individual financial opportunities and an increased quality of life when immersed in urban environments? From whichever angle one chooses to approach the on-reserve, off-reserve issue, it is clear that there exists a gap in logic when allocating funds to the Canadian populace on equal terms. Government subsidy is an important aspect of any community's development and sustainment of resources, especially in areas of smaller population where it can be cumbersome to garner viable economic initiatives. There are currently 615 First Nations communities spread across the Canadian landscape, where 528000 inhabitants are currently distributed amongst those settlements. ${ }^{8}$ This means that reserves are on average only 856 residents in size. Among a few additional factors, in order to reside on reserve land, members must first be part of the Tribe to which the land is associated. 
Each Tribe is composed of different Bands, requiring that members must first be of the specific tribe in order to be a part of the band which occupies the territory. Becoming a new member of the band can be achieved either through ancestral ties or through marriage. Only once they are members of the band, can they officially reside on the reserve land. These dynamics lead the population amongst reserve land to be distributed quite unevenly, leaving some reserves with a fairly large population and others with extremely small populations. Economic conditions on reserve are also largely dependent on geographic location and proximity to other larger city centers. Reserves in remote areas of the country would have a much more difficult time establishing any strong economic ties, also often leading to poor infrastructural conditions. The reason that the large majority of Aboriginal settlements are located where they are today is not at all by the will of First Nations peoples; they were placed there by a colonial government stripping them of their ancestral aboriginal territory. For one, the entire city of Toronto including many of its suburbs is built on traditional aboriginal land belonging to the Mississaugas, comprising of roughly 100000 hectors. Today the Mississaugas are left with a 2400 hector reserve west of Toronto, measly in comparison to the land they historically occupied. The land claim dates back to 1787 when one of King George the third's agents allegedly signed a treaty with the Mississaugas, surrendering their land North of Lake Ontario and is currently being investigated for its validity. ${ }^{9}$ 
SECTION 1

First Nations and

the Canadian Fabric

\section{Attawapiskat}

First Nations community located in Northern Ontario. The traditional territory of the band extends far past the boundaries of the reserve. The band has approximately 2800 members with roughly 1500 living on reserve. Due to its remote location, the community is accessible only by train, and via a winter ice road between the months of January and March. Living conditions on reserve are quite poor, and have been considered on par with many third world nations. Government assistance to mitigate issues of poverty continues to be limited.

Attawapiskat First Nation. Canadian Buisness Ethics Research Network. http://www.cbern.ca/ research/projects/workspaces/ cura_project/case_studies/attawapiskat_first_nation/

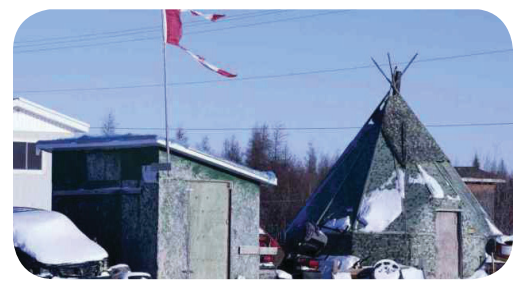

Photo depicting "third world" living conditions on the Attawapiskat First Nations reserve. A torn Canadian flag flapping in the background, serves a stark reminder that the Canadian government has done little to aid the situation.

Attawapiskat, ON. http:// o.canada. com/2012/12/02/neighbouring-reserve-to-attawapiskat-declares-fuel-housing-emergency/ . retrieved 2012/12/18
When assessing the quality of living conditions in First Nations reserves, it becomes clear that there is a large range of citizens living in conditions that would have any Canadian scratching their head in disbelief. Take the community of Attawapiskat for instance. The Attawapiskat reserve is located in Ontario, north of Timmins, on an off-shoot river of Hudson's Bay. The community declared a state of emergency in 2011 due to the severe lack of proper living conditions. It was reported that 5 families were living in tents and 19 families living in sheds all with no running water or electricity, leaving them to use plastic buckets for sanitary purposes. The reserve is in such a remote area that no roads reach its location, other than an ice road that forms in winter months. All other access to the community must be done by train or air travel from the Timmins airport. Similar conditions are found in the Northern Ontario community of Pikianigikum. The appalling living environment found Pikianigikum, on par with many other third world countries, has spurred a rash of substance abuse problems and high suicide rates among youth. ${ }^{10}$ Members of the community are simply finding no other way to cope with the inexplicably low quality of life. In a country like Canada, with every means possible to rectify these issues, it is extraordinarily difficult to understand why communities like these continue to be overlooked. The sheer notion that nearly 2 000 First Nations households do not have running water or means of septic disposal, should undoubtedly resonate deeply. ${ }^{11}$ Everyday most of us take for granted certain luxuries like turning on a water 


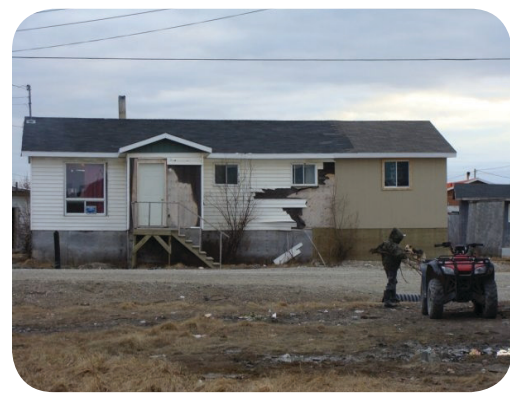

Photo depicting a home in disrepair, on the Attawapiskat First Nations Reserve.

Attawapiskat, ON. http://www. torontosun.com/2011/12/21/un-blastswrong-minister-over-attawapiskat. retrieved 2012/12/18

Chief Terrance Paul

Terry Paul is the Chief of the Membertou, a position he has held since 1984. During that time, Paul has guided his community and administration into one of the most open and efficient native communities in the country.

fixture, or simply occupying a comfortable dwelling. These two First Nations are just a small sample of poor on-reserve living conditions that can be seen across Canada. ${ }^{12}$

Fortunately, however dire the living situations are for many Indigenous communities in the Canadian fabric, some have turned the tables and are enjoying rather prosperous times. The population of Membertou located in Cape Breton, Nova Scotia, has managed under the governance of Chief Terrance Paul to become a kind of economic hub for the region, attracting business and tourism to the area. They are involved in corporate sectors such as lottery and gaming, technology, and even renewable energy research. The income generated through these various sources allows them to be more autonomous while lowering their dependence on government funding. ${ }^{13}$ The economic dexterity also funds possibilities for architecture and infrastructural growth within the community, further strengthening their culture as well as their place amidst the Canadian context. This community does however starkly contrast the many nations suffering through impoverished living conditions. In our modern age, notions of architectural language and cultural authenticity are all the more difficult to ask if economic stability to fuel these discussions does not exist. 


\section{The People OF THE Garden River}

Located 130 kilometers north of Canada's capital, is the Aboriginal community of Kitigan Zibi Anishinabeg. The town is directly adjacent to the Quebec town of Maniwak to its North East, bounded by the Eagle River to the North and Northwest, as well as by the Desert River to the East. The reserve spans area of roughly 184 square kilometers (18 437 hectors or 45559 acres), hosts 27 lakes and has a current population of just over 1500 on-reserve citizens,

which is on a continuous rise. ${ }^{14}$ The reserve is largest among all Algonquin settlements in both land area and population. The reserve was delineated on May 31, 1850, and was then officially sanctioned on August 30, 1851, with restriction that the overall area allotted to the various Aboriginal tribes residing in Quebec would not exceed 230000 acres. Two years later on June 8,1853 , the distribution of the lands was finally proposed amongst tribes by John Rolph, who was at the time Commissioner of Crown Lands. The reserve land allotted to Aboriginals residing in the township of Maniwaki amounted to roughly 45750 acres, slightly more than what is currently formally occupied by the band. ${ }^{15}$ It was originally intended that the land was to accommodate the Algonquin, Nipissing, and Attikamek tribes, but is today held solely by the Algonquin band, Kitigan Zibi Anishinabeg. ${ }^{16}$ Following the official delineation of land in the township of Maniwaki, many of the Algonquin people fled their previous installment at the Oka mission situated on the Lake of Two Mountains, where they resided since 1720 . The Algonquins used the mission primarily as a base point from which to travel extensive distances. Nomadic by nature, they often travelled in pur- suit of traditional livelihoods such as hunting and fishing. Navigation from the mission to distant lands was made possible by virtue of its direct connection to the Ottawa River and to the St-Laurence River. Due to the expansive river network, other Algonquin groups were also scattered throughout the Ottawa Valley trading fur and goods with the Hudson's Bay Company. These bands were frequently visited by missionaries at their trading posts, encouraging further settlement from white populations, which was deemed to have driven away many fur bearing species. Missionary work directed by the Oblate Fathers of Bytown (Bytown being the former name of Canada's capital city, Ottawa) lead to the founding of a mission at the confluence of the Gatineau and Desert River, Quebec in 1851. The mission was established for Aboriginal groups that gathered there and for lumbermen who had begun settling in the area following the sanctioning of reserve land by the pre-confederation government. The white settlers dubbed the area near the confluence, "Terre de Marie" (Maryland), or Mani-waki (Land of Mary) as referred to by the Algonquins. The Algonquins also referred to the River Desert as Kitigan-sidi (River of Gardens), due to its shoreline of farmed areas. They called themselves the Kitigansibiwiniwag (The People of the Garden River), which eventually lead to their current name, Kitigan Zibi Anishinabeg, directly translating to "Garden River Algonquins". ${ }^{17}$ The dynamics of white settlers and Aboriginal peoples occupying the same area eventually shaped the bordering condition that exists today between the two communities.

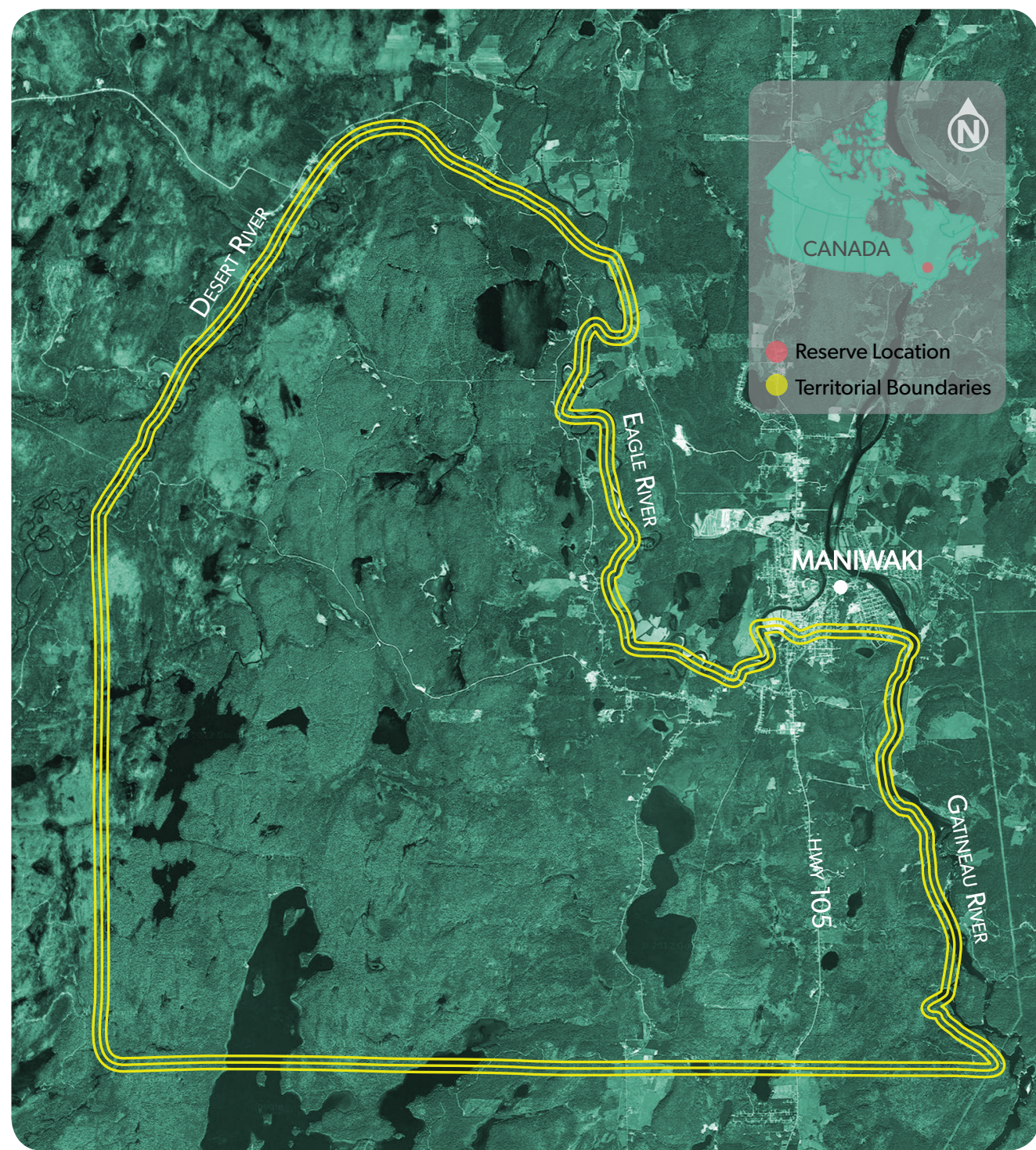

MAP

KITIGAN ZibI ANISHINABEG
Satellite imagery denoting the territorial limits of the Kitigan Zibi Anishinabeg First Nations Reserve.

Graphics by author. 2013/03/26

SATELLTE Kitigan Zibi Anishinabeg and Maniwaki, Google IMAGERY: Earth (version 7.0.3.8542), Google Inc. (2012). 


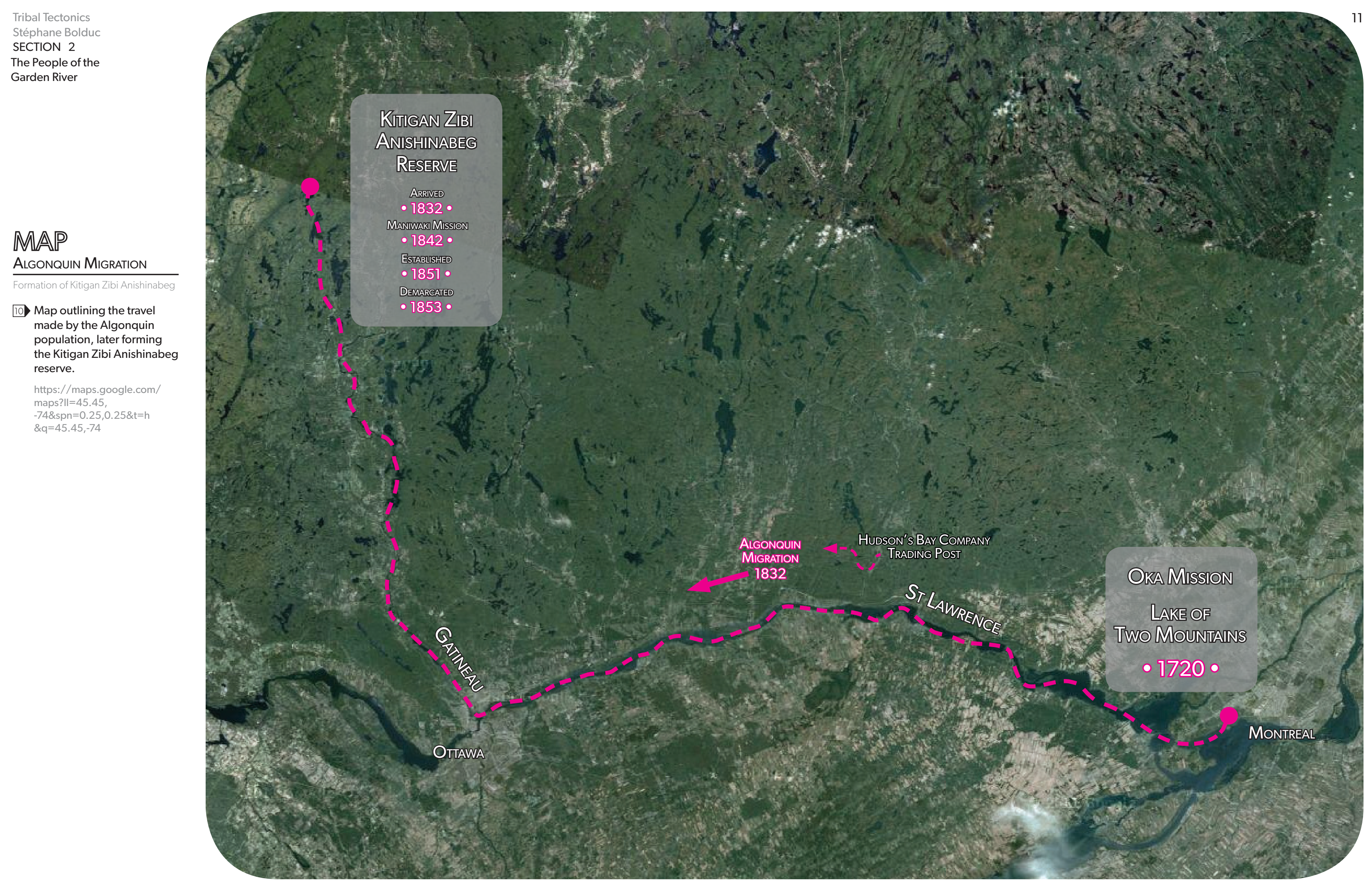


THE PEOPLE OF THE GARDEN RIVER ...

2.7 Territorial LAND Division 
Frank Gouldsmith Speck (1881-1950)

American anthropologist specializing in the study of Algonquian and Iroquoian peoples of Canada and the United States. As a strong proponent and advocate of Aboriginal rights, Speck's work provided a basis from which representations of Aboriginal territoriality could be developed. His work also took a stand against racism in specific governmental policies of assimilation directed towards First Nations people. In certain cases this would involve direct confrontation with government officials.

Siomonn Pulla. "Anthropologica advocacy?: Frank Speck and the mapping of Aboriginal territoriality in eastern Canada, 1900-1950." Ottawa: Department of Sociology and Anthropology, Carleton University, 18 April 2006. p.219-220
TERRITORIAL LAND DIVISION

In 1761, it was reported that land among the Algonquin nation of Lake and Two Mountains, was divided using a family hunting territory system. They were subdivided through ancestral inheritance, and were upheld by exceedingly stringent rights of property. ${ }^{18}$ Hunting on neighbouring territories often carried harsh consequences. Permission to utilize adjacent hunting grounds was however granted in times of drought, with understanding that reciprocity would be honoured. When game supplies on a family's land dimished, adjacent territories might have the opposite fortune. The favour was usually granted in hope that the good deed would be returned in the situation was at some point reversed. ${ }^{19}$ This territorial system was central to the way Aboriginals shared land, and demanded that families respected each other in order to ensure each other's survival.

\section{A study of Frank G. Speck's anthropological}

descriptions of the Family Hunting territory scheme illustrates his direct involvement with Aboriginal peoples in the early $20^{\text {th }}$ century. Frank Speck's representations of Aboriginal territoriality provided insight into the practical, historical and spiritual premises of Aboriginal people's distinct cultural traditions. Speck's work enabled Aboriginal peoples to challenge the Canadian government's strict management and regulation of their traditional land use systems. The contributions he has made to reinforce the Aboriginal population's claims to laid ownership has helped counter the intellectual 
and scientific framework the government had enforced, attempting to delegitimize First Nation land entitlement. European colonial power structures were complex and multifaceted, relying on the delineation of authoritative parties in order to govern Aboriginal populations in Canada.

Canadian colonialism is thus born out of a system borrowed from the British government by the emerging Canadian governmental system finding its beginnings in the early $19^{\text {th }}$ century. They ported over a scheme of land transfer and an administrative regime utilized by the British imperial command, adapting it to suit the evolving national development on this cross-Atlantic new found land. ${ }^{20}$ Intrigued by the complexity of the relationship between First Nations people and the newly formed Canadian government, Speck began to shift his analytical approach. In 1912, Speck shifted from studying "theoretical models of social organization" to "representations of Aboriginal territoriality" which tended to the struggles between both parties involving Aboriginal land and resources. ${ }^{21}$

Frank Speck's writings on the family hunting territory system are very well received, however not without some opposition. Many scholars have different opinions into the workings of Aboriginal land division amongst the greater populace. In the 1950's, Eleanor Leacock argued in her Phd thesis that the hunting territory system did not stretch as far back into ancestral heritage as believed by Speck. Leacock speculates that the system is a product of the European fur trade, forcing families to protect their source of income. ${ }^{22}$ The fur trade 


\section{SECTION 2.1}

The People of the Garden River [Territorial Land Division]

Graphic representation of wild farming. It can be described as a conservational practice, where Aboriginal families would ration the amount of animals to be hunted, in order to ensure stability to the overall health of the ecosystem they depended on to survive.

graphic by author. 2013/01/07

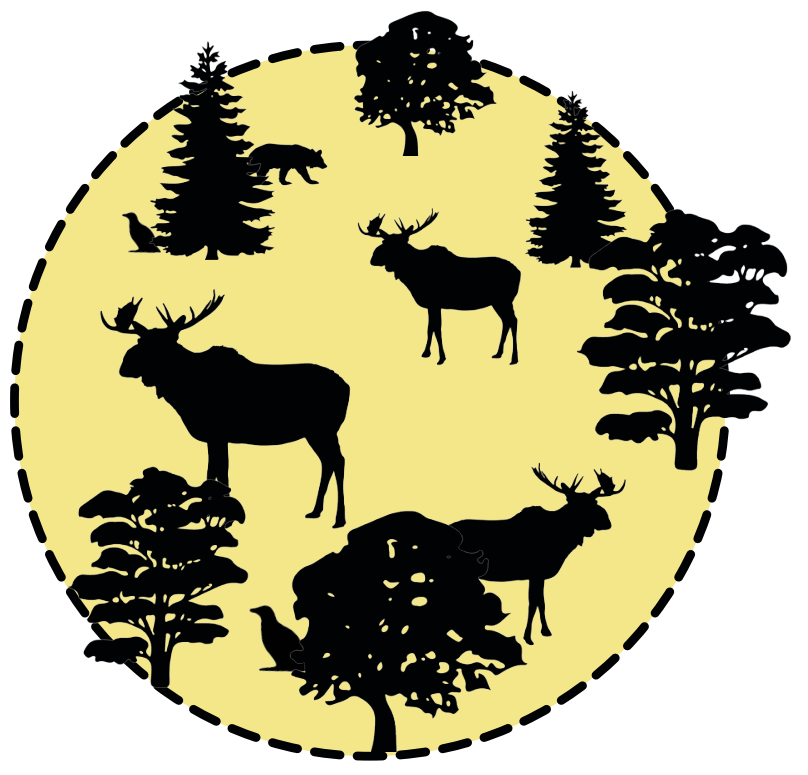

being highly lucrative at the time, takes a product crafted by nature, used by Aboriginals for means of survival, and spins in into a roaring capitalistic system set in place by European settlers. Although connections can be made with where Leacock draws her argument from, my tendency is to argue against it. I believe that because systems like domestic farming did not exist until Europeans transplanted domesticated animals into the landscape, families had to conserve their resources in order to ensure their continued survival. Aboriginal peoples had a very close relationship with nature and understood quite deeply that a harmonious framework was the only way to sustain and replenish resources. Slaughtering heaps of game or moose might yield short term gains, but could mean that future generations of those animals in the area would suffer. The sustainment of resources is in itself is a form of farming, or one could say "wild farming", and it is for that reason that I tend to side 
Frank Lloyd Wright (1867-1959)

American architect of international fame. A large proponent of buildings at harmony with people at their surroundings, he developed a philosophy called Organic Architecture. He is best know for his design of the Falling Water house, located in Pennsylvania.

Mike Brewster. "Frank Lloyd Wright: America's Architect." Bloomberg Buisness Week. http://www.businessweek. com/stories/2004-07-27/ frank-lloyd-wright-americas-architect. 27 July 2004. with Speck in saying the family hunting territory system stretched far back into First Nations heritage.

Today, there exists on reserve a situation that is peculiarly similar to Frank Lloyd Wright's Broadacre City Plan, where every citizen of the United States would be given a minimum one acre plot of land. The concept was first formulated in the late 1930's through his book The Disappearing City, and was later refined in the 1950's as part of his book titled The Living City. His revolutionary ideologies virtually acted as an early version of Critical Regionalism, a concept later developed in large part by Kenneth Frampton in the 1980's. Central to the Broadacre model was in Frank Lloyd Wright's words, "...a matter of the right kind of building in the right way in the right place for the right people." He then touches on the importance of economic sustenance as a public need, not as a commodity but merely as a method of exchange. Wright dives into the wide breaths of his philosophies of organic design, mainly in relation to man occupying space, but also broadens the concept to include economic modality. Referencing the modern economic paradigm as an obstruction to the evolution of creative architecture, he states that architecture must encompass Place, Time and Man. Along with these factors, they must be placed in conjunction with the various complexities of the modern age in order to make great life possible. ${ }^{23}$ He speaks of an organic economy which is constantly influx, under continuous adaption, transformation; "an element of beauty". He saw the 


\section{SECTION 2.1}

The People of the Garden River

[Territorial Land Division]

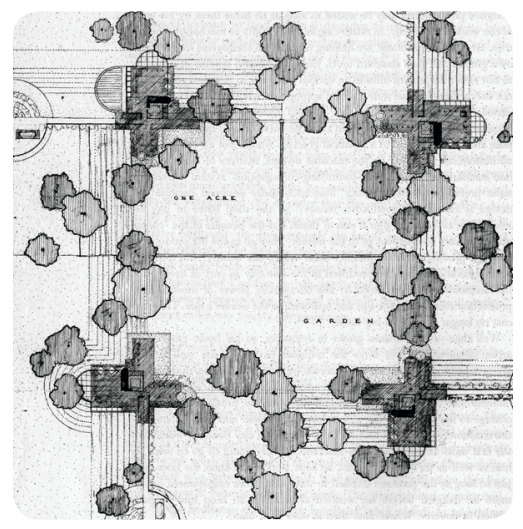

Drafted hand drawing of an exterior plan view depicting a quadruple housing cluster as part of the Broadacre city proposal.

Frank Lloyd Wright. The Living City. New York: Horizon Press, 1958. p.151

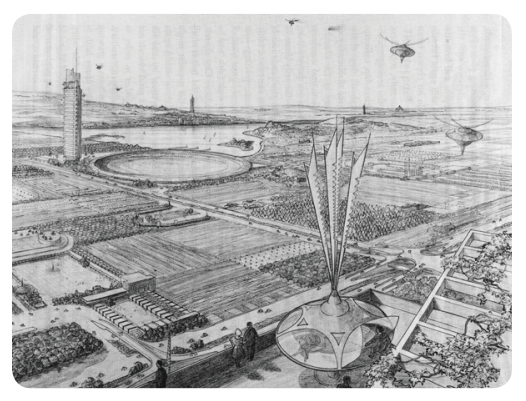

Rendered hand drawing of an aerial view depicting scattered high rises, farm land, higways, and numerous circular helicopters flying above Broadacre City's countryside.

Frank Lloyd Wright. The Living City. New York: Horizon Press, 1958. p.181

Physical Model of Stadium and Circus for county fair as well as other various programmic functions. modern economic system and architecture as one reciprocal unit, wherein a failure at the economic level results in a systemic collapse at architecture's root. ${ }^{24}$ Although conceptually his ideals are rather admirable, his concept begins to falter once it materialize into a physical proposal. Lloyd Wright's vision was that, with the birth of modern technology, man should not be confined to dense areas. He saw the city of the future as a widely spread organism by which every family is free to occupy plots of a least 1 acre in size. Scattered throughout are portions of farmland, some elongated towers illustrating nodes of density and uninterrupted traffic overpasses. Although he had no way of knowing it, these concepts of mass de-centralization and thinly spread urban planning principals are precisely where our modern cities have failed. In short, Frank Lloyd Wright's Broadacre vision paints an embellished picture of the suburbia we know today; de-centralized, inefficient, and placeless.

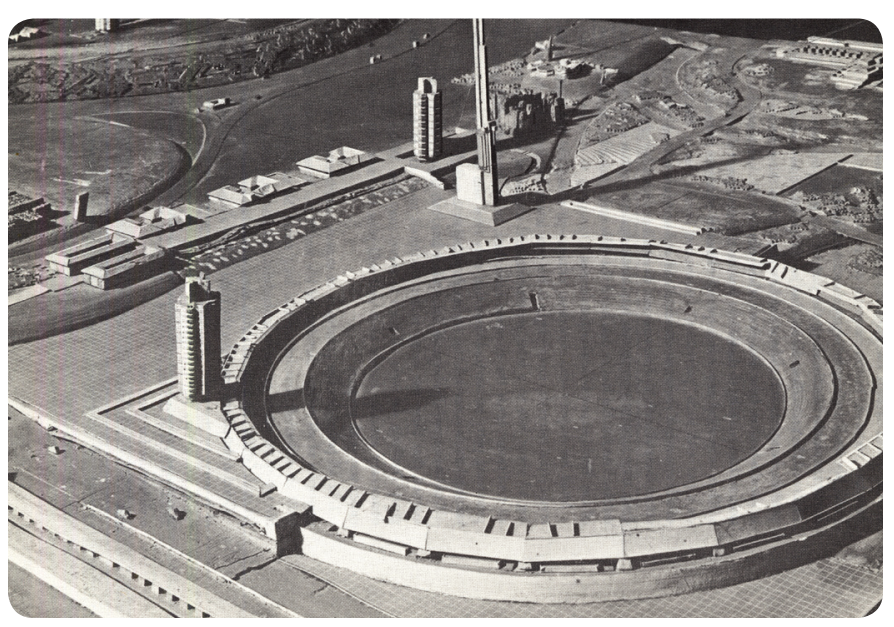


SECTION 2.1

The People of the Garden River

[Territorial Land Division]

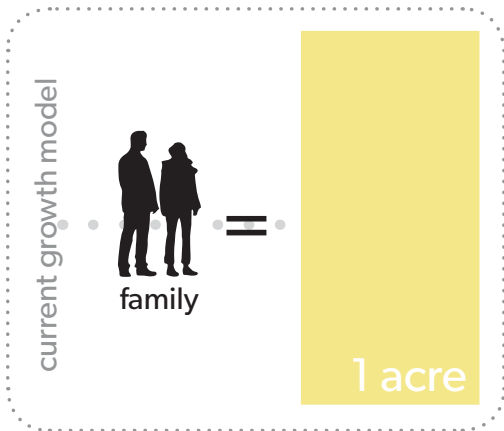

5 Graphic representation the current growth model for the Kitigan Zibi Anishinabeg community, where every new home built is allotted 1 acre of land.

graphic by author. 2013/01/07

Gilbert Whiteduck

Chief of the Kitigan Zibi Anishinabeg band since 2008. A well received and respected leader in the community. Is a strong advocate of Aboriginal rights and claims to territory never seeded to government. Amongst others, land disputes (some dating back to the 1800's) amounting to over 500 acres of land with bordering town of Maniwaki remain in the discussion phases.

Whiteduck, Gilbert. "Evidence of meeting \#22 for Aboriginal Affairs and Northern Development in the 41st Parliament, 1st Session." Aboriginal Affairs and Northern Development . Parliament of Canada, 2012. http://www.parl.gc.ca/HousePublications/Publication.aspx?Do$\mathrm{cld}=5366598 \&$ Language $=\mathrm{E} \&$ Mode $=1$

6) Marcel Brascoupé

General construction contractor for the Kitigan Zibi Anishinabeg Band and vice president of the Canadian Association of Radon Scientists and technologists. He is responsible for much of the building activity on reserve as well as the mitigation of radon gas issues.

Canadian Association of Radon Scientists and technologists. http://www.carst.ca/ en/directors.html
In Kitigan Zibi, a similar situation occurs, whereby every new house built is allotted a one acre plot of the land. ${ }^{25}$ The scheme although in a Utopian sense appears suitable on paper, is unsuccessful when you factor in infrastructural development, the mobility of people within the community, and the reinforcement of cultural qualities by virtue of human connectedness. The reality is that when a system of large plot allocation is in place it inherently introduces sprawl, even with the relatively small population residing on reserve.

At first glance one might draw similarities between the generous land allocations and the large hunting grounds found in the family hunting territory system. There is undoubtedly something attractive in residing on a large plot of land that can be called your own. There also may be some form of historical connection with traditional style living, by which the large plots might deliver to some extent. The reality is however that the one acre plots are in place for reasons of utility for septic systems and wells, but with a newly introduced municipal water and sewer system, this sizing is beginning to lose relevancy. The large plot allocations are causing strain on the community's development by forcing the band to keep pace with the rapidly growing population on reserve, extending infrastructure to homes outside of the central core. After a few meetings with Kitigan Zibi's Chief Gilbert Whiteduck, and construction specialist Marcel Brascoupé, it becomes increasingly clear that mending the issues surrounding the current housing situation remains a challenging endeavour. ${ }^{26}$ 
THE PEOPLE OF THE GARDEN RIVER ...

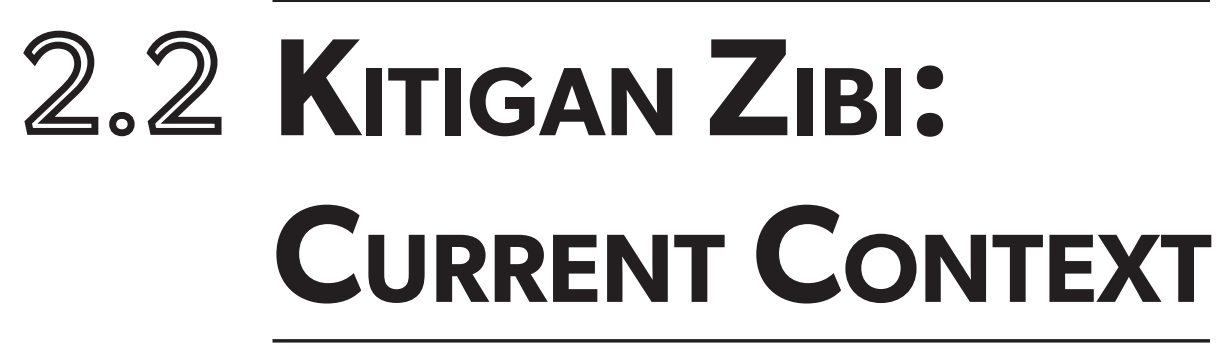




\section{KITIGAN ZIBI: CURRENT CONTEXT}

Owning a piece of property on reserve is quite different than purchasing land in any other city throughout Canada. Canadian rights of property dictates that on reserve, the band is the land proprietor, leaving individual land ownership to be acquired through any four types of property rights regimes. The four different regimes are: customary rights, the independent land codes developed under the First Nations Land Management Act, leases, and Certificates of Possession (CPs). Of the four, the most prominent form of ownership is Certificates of Possession, with roughly 145000 CPs issued to individuals on 301 reserves since 1888 by the Canadian government. Only band members can acquire a Certificate of Possession and allocation must be approved by the Band Council as well as Indian Affairs. By acquiring a $\mathrm{CP}$, the individual receives similar property rights to residents residing off reserve, with a key difference being it is not entitlement to ownership but a right to possession. What this means is that a banking institution would have considerable difficulty lending capital to someone looking to purchase property on-reserve. The primary concern a bank would have is that they would be unable to recover assets in the case of an individual defaulting on their loans, as only band members are entitled to possession of reserve land. ${ }^{27}$ Dealing with the right of property is one issue, but then comes acquiring the adequate funds to secure a proper dwelling unit. Because 


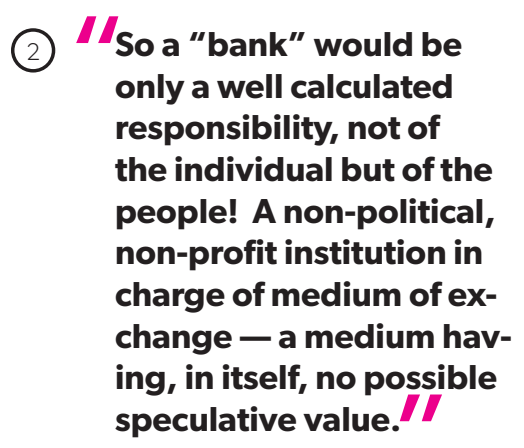

-Frank Lloyd Wright

Frank Lloyd Wright. The Living City. New York: Horizon Press, 1958. p. 167 individuals have rights to the property and are not actually property owners, First Nations individuals have an exceptionally difficult time convincing banks to grant them a mortgage. From the bank's perspective, if the owner of the property defaults on their loan, they have no power to seize any of their property as they normally would in a standard situation, because they were not the owners in the first place. The burden of fronting capital to members of the community is often taken on by the Band, becoming a kind of middle man between the individual and the financer.

The dichotomy between citizens occupying property on or off reserve makes future development on reserve quite complex and multi-faceted. In Kitigan Zibi the majority of the central core is actually occupied by individuals with Certificates of Possession, creating a very difficult framework for development into the future because the band does not have access to that prime land. During a conversation with Chief Whiteduck, we discussed the possibility of creating partnership opportunities between the individual property rights holders and the band. He acknowledged that theoretically it sounds like a feasible approach, but in actuality, community members have a difficult time parting with land that has in all likelihood been passed down through many generations of family. Most of the developable land on which the band can access is located away from the central area, meaning that when the band builds homes, they often have to invest in extending municipal infrastructure to reach the new dwellings. Because of these limita- 
SECTION 2.2

The People of the Garden River [Kitigan Zibi: Current Context]

\section{$\mathbb{M} \mathbb{A P}$}

KITIGAN Zibi ANISHINABeg

HOUSING

16 Aerial Photograph at intersection of Kikinamage Mikan and Bitobi road, displaying sparse living conditions on reserve.

Aerial photograph. Natrual Resources Canada. Taken in 2005 recorded digitally June 2012 tions, the reserve is developing today, much like any other suburban community, almost acting like a satellite community to the neighbouring town of Maniwaki. With this relatively standard western scheme, comes a seaming dilution of culture and weakening communal strength due to the sparsely situated living conditions. That being said, I completely sympathise with the attractiveness of having a piece of property that a family can call their own and do not aim to remove that quality in my proposal for potential urban solutions.

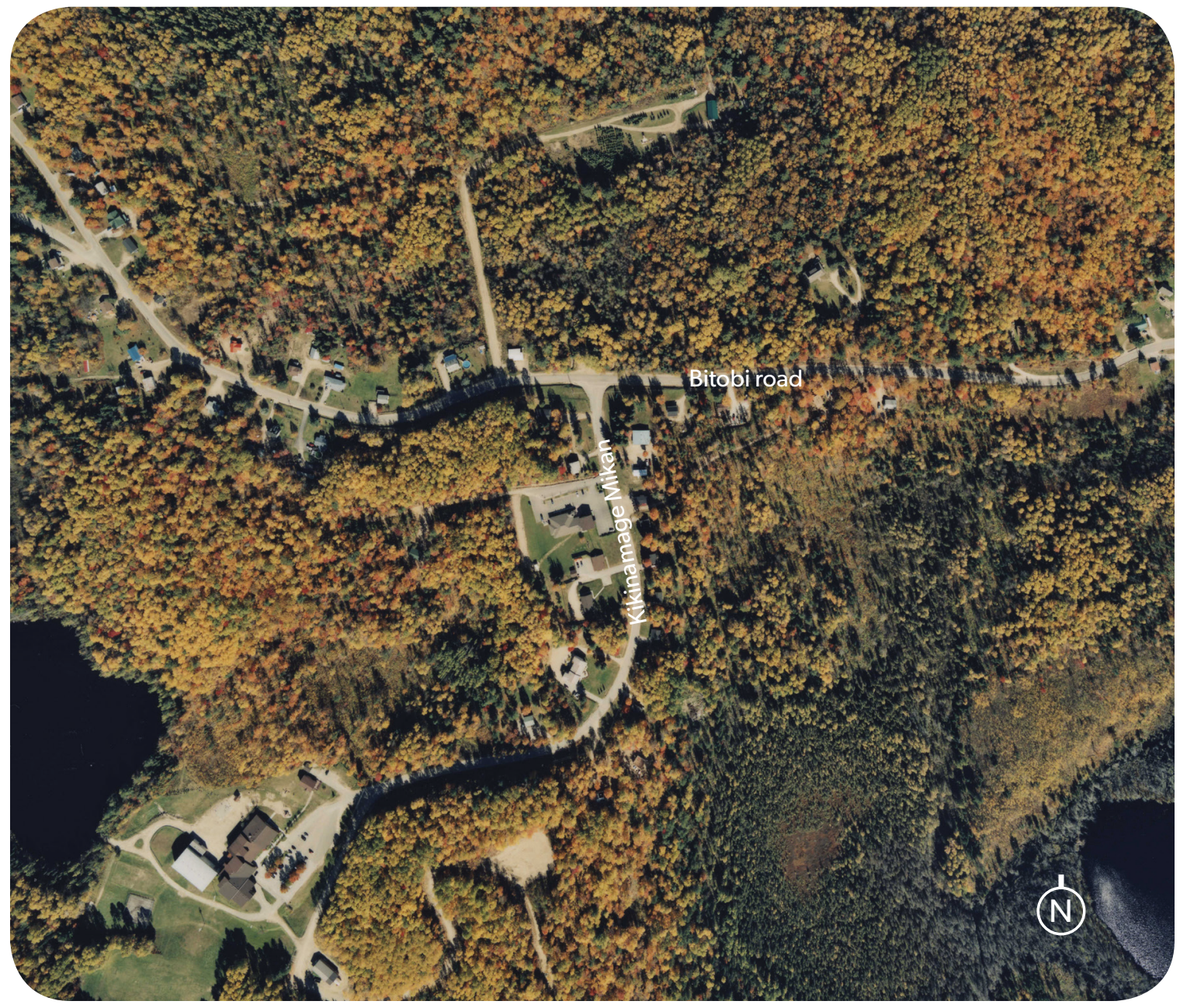


THE PEOPLE OF THE GARDEN RIVER ...

\subsection{Kitigan Zibi: Current Fabric}


As previously mentioned, the band occupies a territory of 45559 acres, bounded by the Desert River on the East, West and Northern limits, containing 27 different lakes. ${ }^{28}$ The western half of the reserve's territory is preserved as an area of limited development, where wild life such as Wood Turtle habitats and vegetation species are protected. Permanent dwellings are not permitted on this portion of the reserve, while camping is permitted in designated areas. This zone contains a region of Maple trees, which Kitigan Zibi operates as a substantial Sugar Bush venture. The Sugar Bush operation occupies 90 hectors of land hosting 17000 tap lines. The end product is a high grade, pure maple syrup produced completely on reserve, by local band members. ${ }^{29}$ The eastern half of the land is considered the development zone, where residential and commercial activities take place. The reserve's infrastructure revolves mainly around three primary roads: Highway 105, Bitobi Road, Pitobig Mikan and Kikinamage Mikan (School Road). Highway 105 acts as a kind of economic axis, Kikinamage Mikan hosts many of the community's service buildings while Bitobi Road and Pitobig Mikan are composed primarily of residential development. The area between Kikinamage Mikan and Highway 105 (using Makwa Mikan road as a limit to the south) is considered to be the area of highest density with approximately 15 key buildings.

The Kitigan Zibi reserve shares a border with Maniwaki to the North with Highway 105 being the 


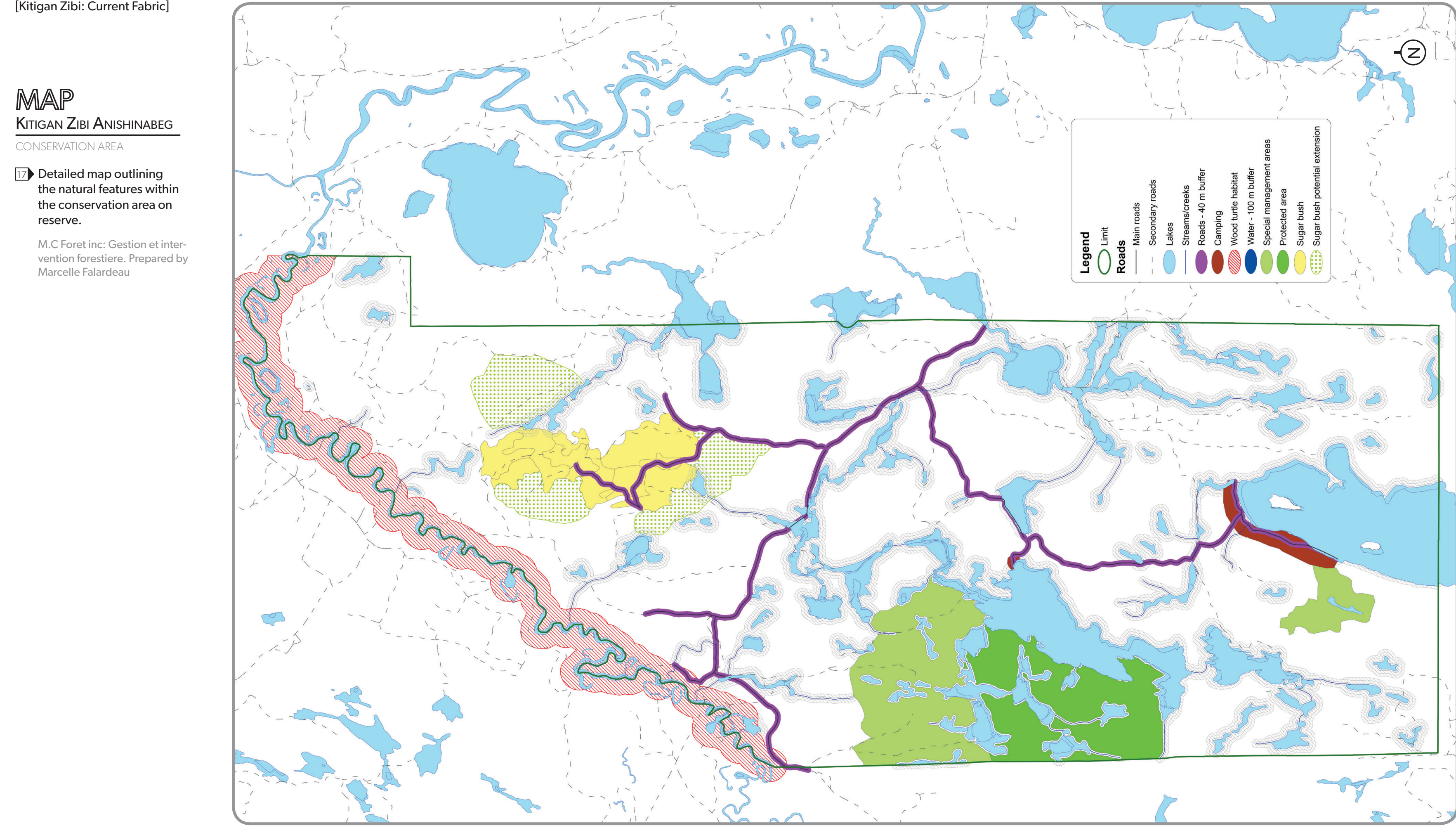




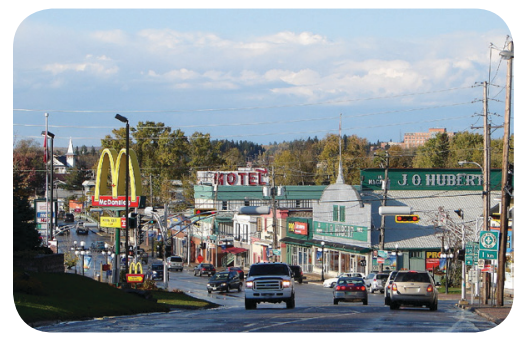

Photo of the town of Maniwaki. Taken near the border between Kitigan Zibi and Maniwaki, towards the north on highway 105.

http://commons.wikimedia.org/ wiki/File:Maniwaki_QC.JPG\#file . captured in 2008

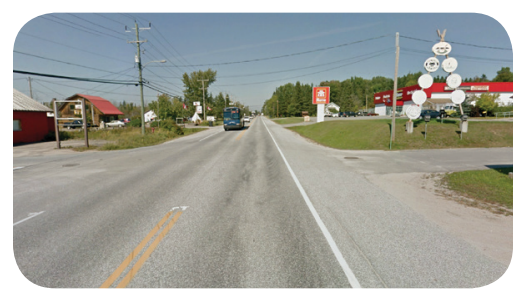

Photo of the Kitigan Zibi Reserve, towards the north at the corner of highway 105 and Makwa Mikan road.

https://maps.google $\mathrm{ca} /$ maps?q=maniwaki\&oe=utf-8\&aq $=$ t\&rls=org mozilla:en-US:official\&client=firefox-a\&um $=1 \& i e=U T F-8 \& \mathrm{hl}=$ en \&s $\mathrm{a}=\mathrm{N} \& \mathrm{tab}=\mathrm{wl}$. captured in 2012 primary link between the two communities. The socio-economic condition amongst Kitigan Zibi and Maniwaki exists as an interdependent relationship each supporting the prosperity of the other. They have co-existed in this manner since the conception of both reserve and town in 1853. As economic generators, Kitigan Zibi hosts a few retail establishments, a cultural centre, a grocery store, a funeral home, construction services, a gas station, and the Awazibi Pure Maple Syrup business, to name the primary contributors. Maniwaki has a much larger assortment of businesses including many restaurants, large commercial franchises, automobile dealerships, taxi services and a saw mill, to name a few. Kitigan Zibi utilizes many services which Maniwaki provides such as waste management and recycling services to compensate for the amenities they do not currently offer. This sharing of economies is a positive sign that both communities are thriving parallel to one another. Kitigan Zibi currently has a population of approximately 1500 on-reserve citizens while Maniwaki currently hovers around the 4000 mark. ${ }^{30} 31$

Kitigan Zibi exists on land which is still bustling with wildlife and easily accessible through the natural hydro-throughways Aboriginal ancestors relied on. With a population growth rate on a consistent rise (most notably between years 2006 to 2011 where the reserve saw a growth of $25 \%$ in their on-reserve population) they have been pushed into a surge of development which they have not been able to adequately adjust to. An increase as significant as $25 \%$ in such a short period of time 


\section{Radon Gas}

A radioactive gas which forms naturally through the breakdown of uranium in soil, rock and water. It can not be detected by the senses, but can be detected with the use of special instruments. Inhaling Radon deposits small particles into the lungs known to cause damage or death to cells. Radon gas is attributed to causing on average $16 \%$ of all lung cancer deaths.

Health Canada. http://www.hc-sc. gc.ca/ewh-semt/radiation/radon/ faq_fq-eng.php\#radon. Modified on 2013-02-04 would put any city on its heels. Kitigan Zibi has had to accommodate over 400 additional inhabitants in a six year period, a heavy burden on existing infrastructural conditions. They have in time placed a substantial amount of effort into bettering the infrastructural conditions on reserve in order to accommodate the sizeable growth. They now have a municipal water system that services nearly $45 \%$ of the population, accounting for the portion of the population living in the core region of the reserve. Citizens which reside outside of the core's boundaries rely on wells and septic systems. In comparison to the rest of Canada, due to a relatively low land area to population ratio, many people across the country live on land disconnected from city infrastructure, thus wells and septic systems are not uncommon.

Among being particularly expensive to install large expanses of underground municipal water lines, another issue plaguing Kitigan in regards to housing, eludes concern at first glance. In the early 1990's it was discovered that many homes on reserve were experiencing problems with radon gas infiltration. 79 homes were tested between 1991 and 1993 by Health Canada for Radon Gas with levels ranging between 19.3 and $414.9 \mathrm{~Bq} / \mathrm{m}^{3}$. In 1990 the recommended actionable level was $800 \mathrm{~Bq} / \mathrm{m}^{3}$ but was later lowered to $200 \mathrm{~Bq} / \mathrm{m}^{3}$ in June $2007 .^{32}$ These high levels of gas affect not only the air quality within homes but also the quality of drinking water available from certain wells. When water quality is concerned, Radon Gas is one amongst a few other problematic substances such as Radium 

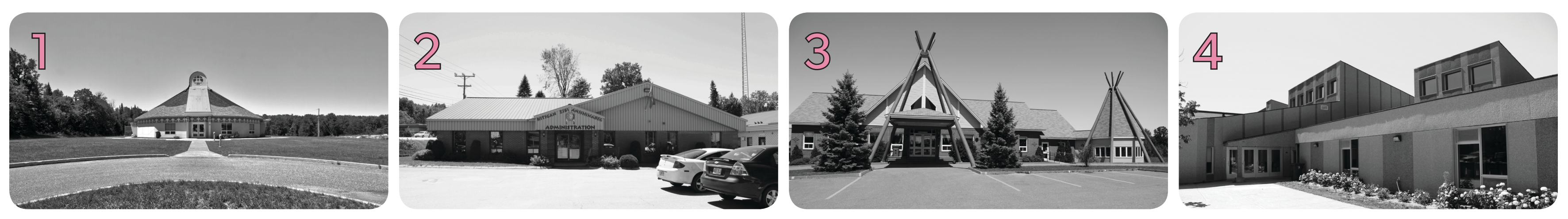

20] Cultural Centre [54 Makwa Mikan Road]

21] Band Council Office [1 Paganakomin Mikan Road]

222 Wazoson Childcare Center [38 Paganakomin Mikan Road]
Photo: Bassam Daoud. Kitigan Zibi Anishinabeg. 2012

233 Kikinamadinan Elementary \& High School
[4] Kikinamage Mikan Road.]
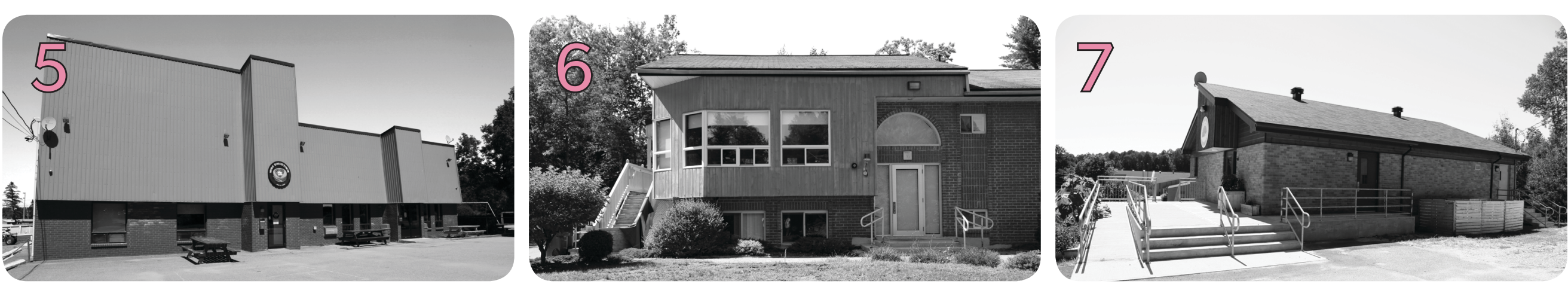

24. Mino Bimadiziwin Good Life Centre [Paganakomin Mik

25 Kiweda Group Home [41 Kikinamage Mikan Road.]
Photo: Bassam Daoud. Kitigan Zibi Anishinabeg. 2012

26 Mokasige Immersion School [37 Kikinamage Mikan Road.]

hoto: Bassam Daoud. Kitigan Zibi Anishinabeg. 2012

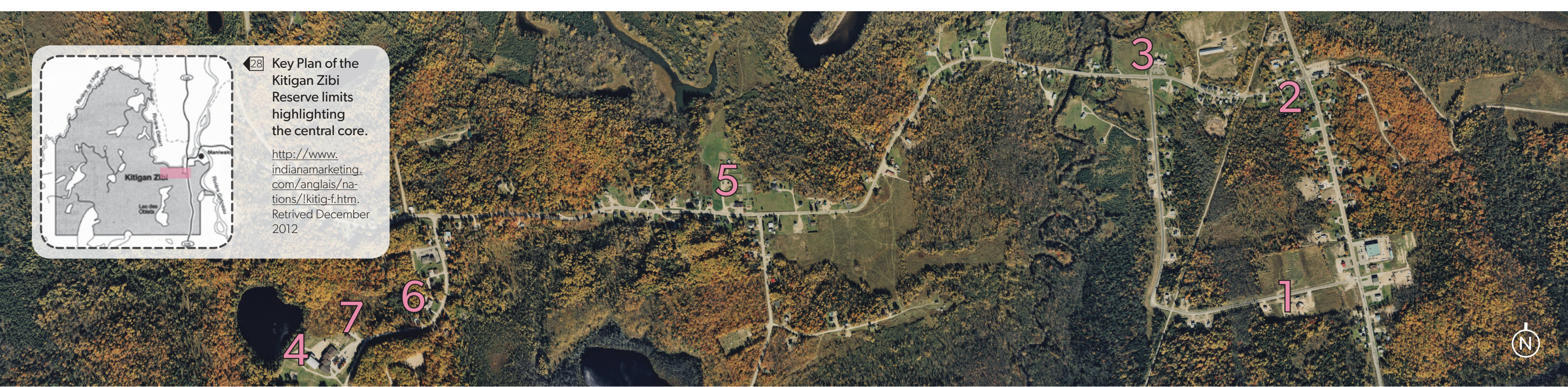


Canadian Mortgage and Hoursing Corportation (CMHC)

Canada's national housing agency, established in 1946 as a governement owned opperation. The agency began by addressing the post-war housing situation following World War II, but has now grown into a major national institution. They provide research into housing technologies, policy and programs, mortgage loan insurance, as well as mortagebacked securities.

Canadian Mortgage and Hoursing Corportation. http:// www.cmhc-schl.gc.ca/en/corp/ about/ . Retrieved 2013-03-30 and Uranium, which have both been found in the drinking water of certain homes on reserve. Since the early 1990's, Kitigan Zibi has been working with the Canadian government on solutions into restoring water quality and air quality in dwellings. Since then, the government has deemed that any long term resolution is too expensive to pursue, leaving them to resort to providing homes possessing contaminated drinking water with shipments of bottled water. ${ }^{33}$ Instead of assisting the community with funding to improve their existing municipal infrastructure, they are still resorting to this temporary solution. Besides being an incredibly wasteful practice, it is also particularly expensive. All of the funding which has been funneled into providing water in plastic bottles could have easily been used to improve infrastructural conditions, which is both sustainable and economically responsible. Unlike the government, in 2009, the CMHC (Canadian Mortgage and housing Corporation) has provided funding as well as training into mitigating air-born radon problems for roughly 180 homes displaying higher than acceptable levels of Radon Gas. 
THE PEOPLE OF THE GARDEN RIVER ...

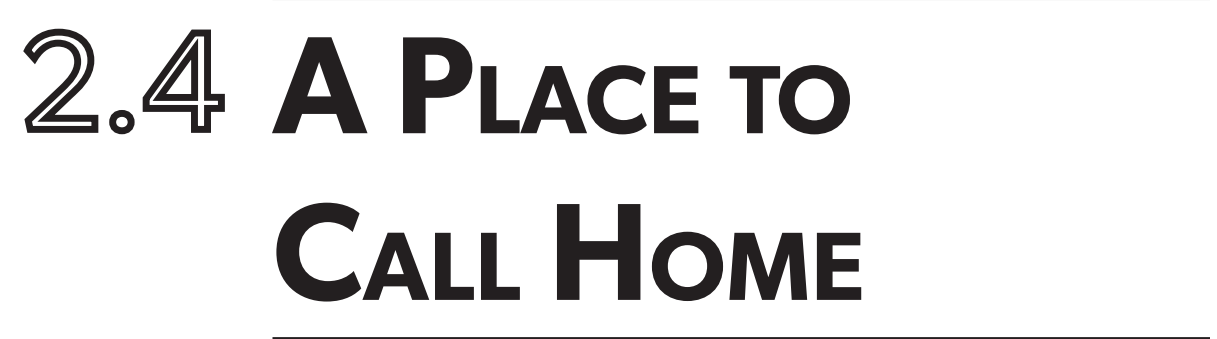




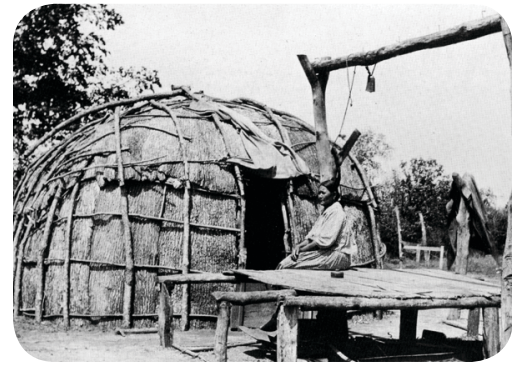

Photo of a traditional Algonquian domed Wigwam using elm bark.

Peter Nabokov, Robert Easton. Native American Architecture. New York: Oxford University Press, 1989. Capured in 1866. p.62

\section{A Place to Call home}

Housing is at the core of human existence; a place of shelter from natural elements, a place of identity, somewhere to escape from the daily grind, a place nestled amongst a collection of entities together forming a community. Like in many other Aboriginal communities, building homes in Kitigan Zibi is a fundamental issue which needs a distinct level of attention. Although the level of housing decay is far less, if not nearly negligible in comparison to communities such as Attawapiskat, the situation is charged with a multitude of other issues that are present in every city across the country. The locations and level of separation between dwellings in the Kitigan Zibi community is largely due to the land area allocations and Certificate of Possession entitlement.

A viable scenario could be to alleviate strain on the community's infrastructure and re-introduce the dwelling as an extension of the human body's connection to nature; much like it existed in the form of a wigwam. Wigwams were used by Algonquins as shelter and were made by materials directly provided by nature, such and branches, birch bark, and tree roots. ${ }^{34}$ If a family chooses to build a home outside the core of the community, the dwelling could exist as a self-sufficient entity amongst the vast landscape, utilizing natural materials and processes. The land on reserve is quite beautiful, surrounded by rolling hills and valleys which form homes for the wildlife that occupies the large territory of the reserve. The home could 


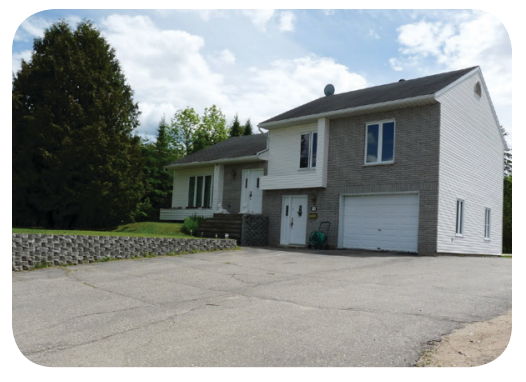

Photo of a 2 storey home with basement, located at 71 Bitobi Road, in the Kitigan Zibi Anishinabeg reserve.

https://ssl.panoramio.com/ photo_explorer\#view=photo\&position=3\&with_photo_ id $=76648993 \&$ order $=$ date_desc\&user $=6987044$. Posted on August 6, 2012. Retrieved on March 30, 2013

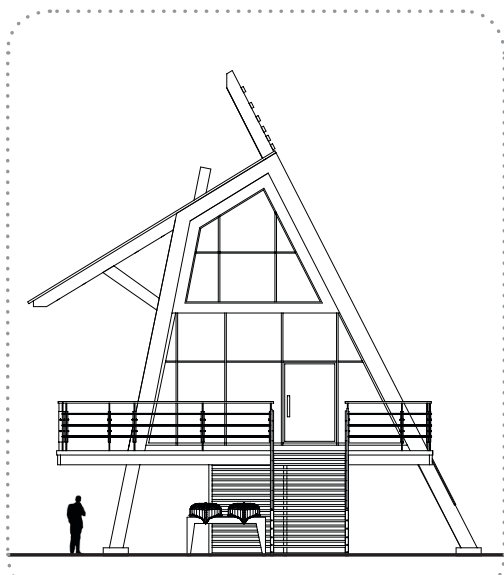

North elevation of proposal for the Kitigan Zibi Anishinabeg community.

Design and graphics by author. December, 2012 use nature as a crux to generate energy and support the life of community members with a net zero impact on the greater environment. There is wealth of natural energy that is so often overlooked but can be efficiently used to shelter and provide a wonderful living environment acting as a connection between humans and nature. A sustainable home provides a viable framework from which an individual or a family could enjoy a traditional way of life while remaining immersed in the ever evolving conditions of modern Aboriginal living.

Building homes with basements has now become an accepted practice in Canada, and Kitigan Zibi has followed suit developing homes with similar design principals, leaving them at risk of potential contaminants entering into the home. There is also a history of flooding in areas near the Gatineau River and the Desert River, with floods having occurred first in 1929 and then again in 1974 in the town of Maniwaki. The flood of 1974 caused damages upwards of 3 million dollars, which were paid for by the province of Quebec. Since then, the Cabonga Dam has been diverted away from the Gatineau River, lowering water levels by 1.5 meters, minimizing the risk of future flooding but not eliminating the possibility. ${ }^{35}$

With the issues of potential radon gas infiltration and flooding in mind, I propose a dwelling placed on stilts, allowing it to sit lightly on the land. Using piled footings instead of typical poured foundation walls, the home will be of very little disturbance to existing natural conditions, thus also avoiding issues of Radon Gas infiltration. Addition- 
ally, the dwelling equipped with an exterior facade of photovoltaic cells allowing the unit to collect energy from the sun, eliminating the need of energy from the municipal grid. The structure is designed utilizing widely practiced light wood framing construction, providing a building system that is both cost-efficient and easily buildable by members of the community. Water is collected from the roof of the building and funnelled into a cistern which can serve a single dwelling or be shared by multiple dwelling units. The water collected from the cistern can be used to flush toilets and for bathing purposed, saving significant amount water from municipal and underground well supplies.

Design and graphics by author. December, 2012

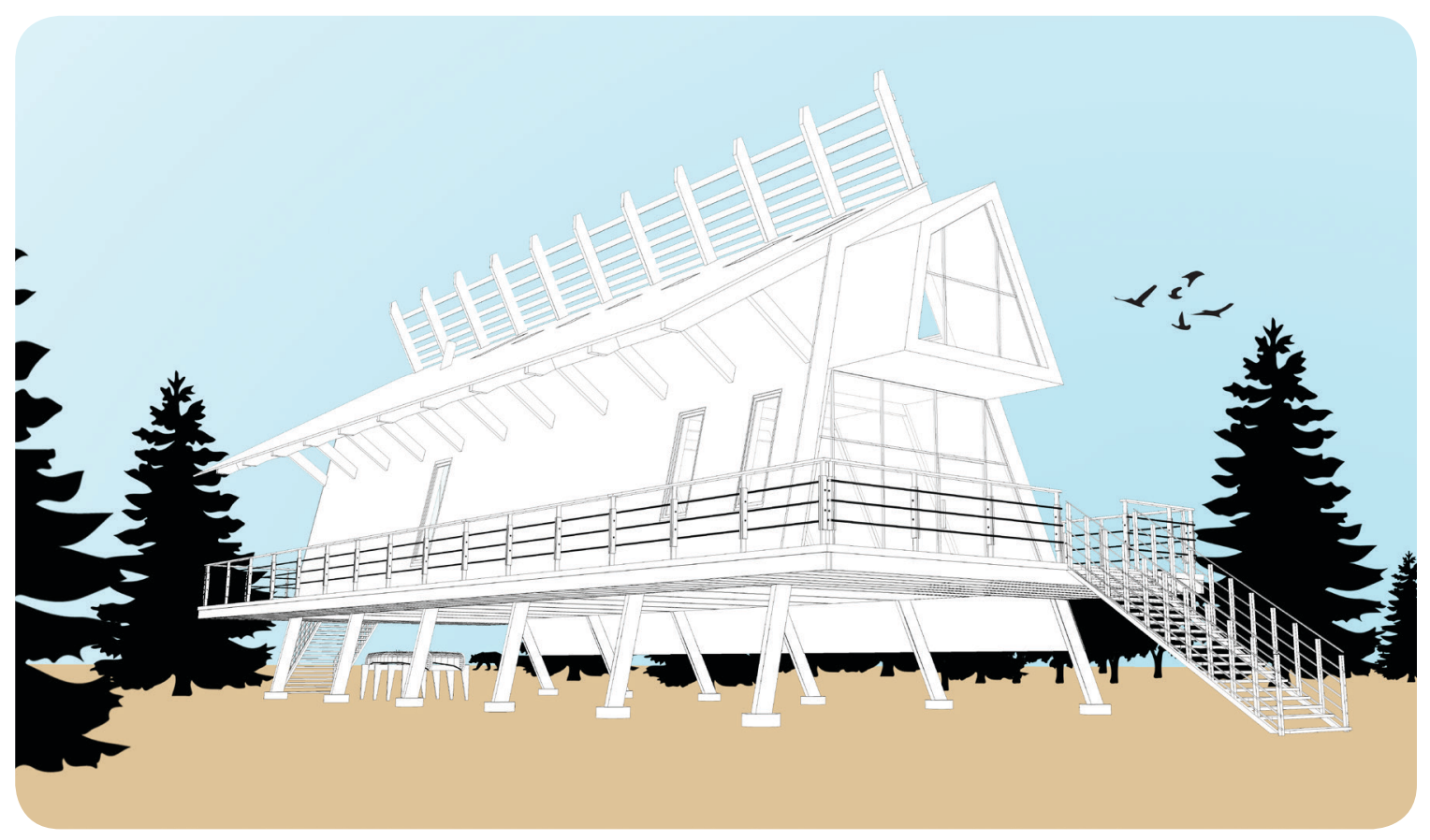


EAST ELEVAUION

33 East Elevation of housing proposal for the Kitigan Z
Anishinabeg community.

Design and graphics by author.
December 2012

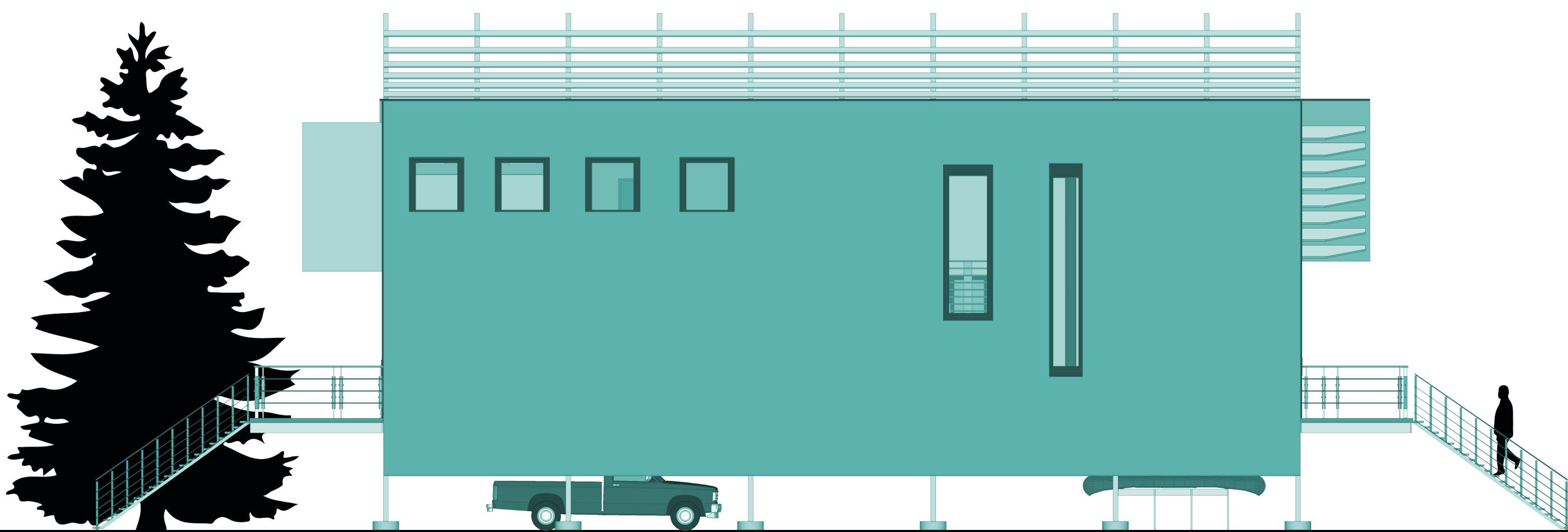




\section{SUSTARNNABBLE TEGLINOLOGIES}

\section{Photovoltaic Cells > Full wall photovoltaics collect and store energy from the sun decreasing the demand on local infrastructure.}

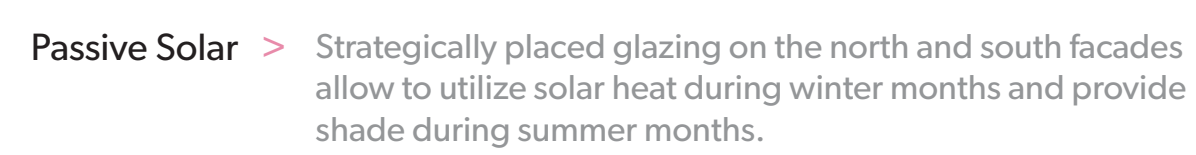

Water Management $>$

A combination between "grey water" and "drinking water alleviate the strain on local water supplies. Rain water is collected in a cistern and is used to flush toilets and water plants, while drinking water is reserved only where necessary. All fixtures in the house are low flow, saving larg

Heat Management Along with passive solar strategies, dual heat management systems are used to maintain heating demands. A combina tion between geothermal heating and wood burning stove supply the dwelling carbon footprint

Unlike traditional asphalt paving, Cellylar Concrete Pavers provide roadways that allow natural conditions to flourish.
Each unit is pre-cast with holes allowing Each unit is pre-cast with holes allowing while still providing structural stability to vehicular traffic.
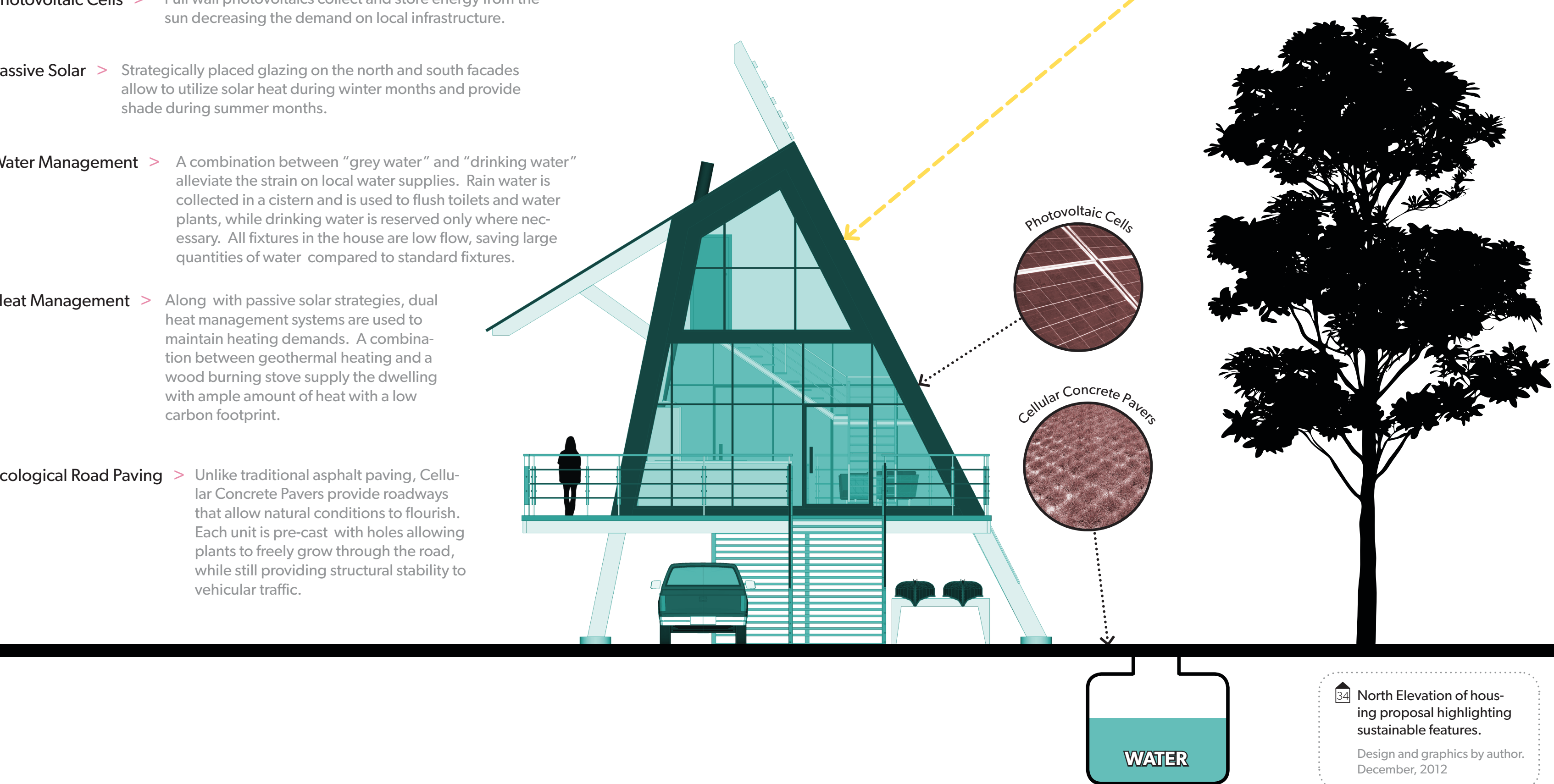

34 North Elevation of housing proposal highlighting Design and graphics by author.
December, 2012 
THE PEOPLE OF THE GARDEN RIVER ...

2.5 At the Core
of the Issue 


\section{Urban Areas}

Statistics Canada classifies urban areas to "have a population of at least 1,000 and no fewer than 400 persons per square kilometre. They include both census metropolitan areas and urban non-census metropolitan areas."

Statistics Canada. Definitions and notes. http://www12.statcan.gc. $\mathrm{ca} /$ census-recensement/2006/ as-sa/97-558/note-eng.cfm (accessed March 30, 2013)

\section{Rural Areas}

Statistics Canada classifies rural areas to "include all territory lying outside of urban areas, excluding Indian reserves as defined above. They include remote and wilderness areas, agricultural lands, as well as small towns, villages and other populated places with a population of less than 1,000 and a density of less than 400 persons per square kilometre."

Statistics Canada. Definitions and notes. http://www12.statcan.gc. $\mathrm{ca} /$ census-recensement/2006/ as-sa/97-558/note-eng.cfm (accessed March 30, 2013)
At THE CORE OF THE ISSUE

A well integrated sustainable dwelling would alleviate some of the complications plaguing Kitigan Zibi's growth in the residential sector. However, providing a good home presents only a small part of the developmental issues the community will face heading into the future. Although Kitigan Zibi is considered to be a fairly small locale, assessing the strengths and pitfalls of larger urban centers could provide clues into how to mitigate the sprawling conditions on reserve.

Before analysing the characteristics of cities, let us first delineate what a city is. To outline in broad perspective, cities are concentrations of large human settlements which organize and fulfill human needs and desires. They can be described quantitatively by population, land area, number of commercial and residential establishments, transportation amenities, services and networks. They often operate under a certain degree of political and administrative autonomy allowing them to quickly tailor and meet the needs of their citizens. While these quantifiable measures accurately depict the broad scheme of a city, they fail to describe the inner workings and human chemistry that make up their urban dynamics. ${ }^{36}$ When assessing the functional characteristics of any successful city, the primary strength is typically a well-developed core; a gathering point. The core acts as an anchor point by which the city organizes itself. It provides citizens and visitors alike with a multiplicity 


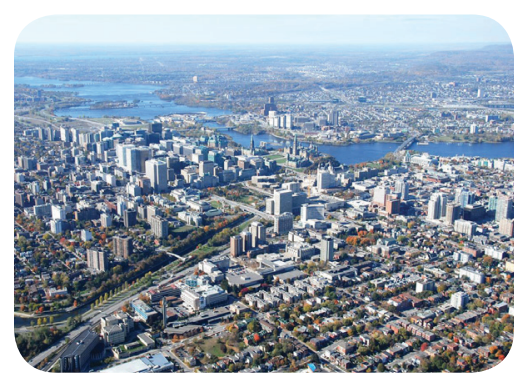

Aerial photograph of Ottawa's downtown core.

Tom Alfoldi. http://www.flickr.com/ photos/tta/4065296617/sizes/o/ in/photostream/. Retrieved on March 30, 2013

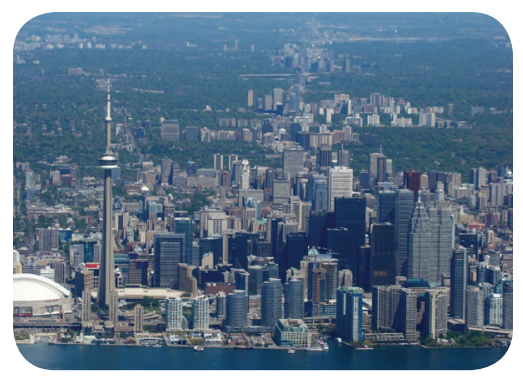

Aerial photograph of Toronto's Lake Ontario waterfront, showing multiple nodes of density in the distance.

http://forum.skyscraperpage. com/showthread.php? $\mathrm{t}=170593$. Retrieved on March 30, 2013 of activities and functional offerings. Many cities possess more than a singular central area, organizing themselves around numerous key points of concentration. The decision of residing in a denser portion of a city revolves around many complex factors but can be broken down into rather simple principals. More often than not, people will choose to reside in a dense urban setting because of the convenience it brings to their lives. The core is most often the primary area in which goods and services can be traded, where economic activity is both strong as well as diverse.

Deciding to live in the central core of a city as opposed to a suburban context could mean that amenities such as groceries, entertainment and leisure are but a few minutes walking distance or a short bike ride away, thus rendering the automobile seemingly unnecessary. For some, the simple notion of diminished automobile reliance is enough to draw them in. However, we can see by tracking the unceasingly rapid growth of suburban communities in any major North American city that building a strong urban core is anything but simple. For all the freedom the automobile has supposedly brought the individual, they have been largely detrimental to the growth of cities in terms of density. In this case, I use the word density to not only describe a large concentration of people but also for a concentration in cultural diversity as well as enriched urban livability. What I mean when I say "urban livability", is that there are places for people to gather, partake in community activities, enjoy natural surroundings, as well as easily acces- 


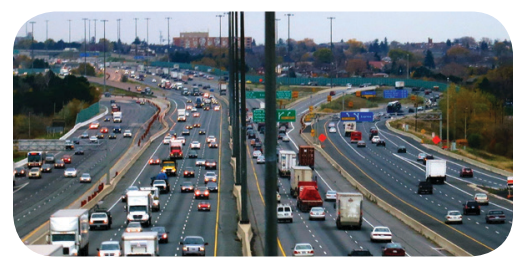

Photograph of the MacdonaldCartier Freeway (highway 401), at a section containing 16 lanes.

Justin Cozart. http://www.flickr. $\mathrm{com} /$ photos/fatguyinalittlecoat/6352225678/. November 14 2011. Retrieved February 2, 2013 sible amenities. Suburban areas often lack many of these essential qualities, or they are simply located at an inconvenient distance from many community members.

We begin to notice these trends and what leads to their development, by analysing current conditions within major Canadian cities. Toronto is a prime example as it is currently the largest with a metropolitan area of just under six million inhabitants. ${ }^{37}$ Due to its vast metropolitan area, Toronto must resort to a labyrinth of highway systems, to herd people back and forth from the suburbs. Toronto's major auto route system is "the 401", formally known as the Macdonald-Cartier Freeway. The 401 connects most of Toronto major satellite suburban communities and is currently the busiest highway in North America. ${ }^{38}$ The issues surrounding the automobile and the development of city centers accumulate as exponentially taxing infrastructural collapses on all fronts. At the larger scale, cities such as Toronto spread their infrastructure over enormous masses of land, covering crucial agricultural land and amassing endless congested roadways. At the smaller scale, citizens might feel like the central core of their city offers little to enhance their quality of life, thus opting to build homes on the outer limits due to cheap land and the expediency of a car. In Mississauga, a satellite suburban community of Toronto, a large segment of the population lives in the city's central area surrounding city hall, a library, an arts centre, a community centre and an enormous shopping mall. The planning of this area nearly alienates 
SECTION 2.5

The People of the Garden River [A The Core of the Issue] the presence of its citizens as it offers little to no options for pedestrians to access these amenities seamlessly. The walk from the residential tower consists of crossing one of Toronto's major transportation arteries, then navigating through a seemingly endless sea of asphalt parking lots and corporate office towers. ${ }^{39}$

Small scale communities like Kitigan Zibi, often operate under the same fundamental principles as any other large urban locale. Just like any city, they organize a collective group of people, providing functions which fulfill their needs both on an individual scale and for the populace as a whole. It also suffers from the some of the major downfalls of urban centers. Similar to Mississauga's problem of inefficiently moving pedestrian traffic, the community fails to provide adequate pedestrian access linking its major buildings and amenities in its area of density. Kitigan Zibi is however, still in its infancy on the developmental stage, but as the community grows and prospers, they possess an incredibly unique opportunity to learn from the downfalls of the modern city and use them to their advantage. When analysing urban conditions we look into categories such as transportation, living conditions, infrastructural amenities, commercial ventures, and entertainment offerings, to suggest design alternatives for future development. Looking into past and present conditions on the Kitigan Zibi reserve, as well as many other communities, will provide insight into fully integrating these multifaceted urban connections. 
THE PEOPLE OF THE GARDEN RIVER ...

2.6 Organic Growth 
SECTION 2.6

The People of the Garden River [Organic Growth]

(7) Jane Jacobs [1916-2006]

Urban activist and writer best known for her 1961 treatise, The Death and Life of Great American Cities. She advocated extensively for new community based approaches and philosophies, emphasizing the importance of local neighborhoods. She approached cities as living ecosystems, suggesting over time that every portion of a city functions together as a dynamic organism evolving according to how people interact with each aspect.

http://www.pps.org/reference/ jjacobs-2/. Retrieved March 30, 2013.

Ken Greenberg

An architect, urban designer and theorist based out of Toronto, Ontario. He has been a pivotal figure on public and private projects throughout North America and Europe for over 30 years. His projects focus mainly on the rejuvenation of city waterfronts and neighborhoods. He is the recipient of the 2010 American Institute of Architects Thomas Jefferson Award for public design excellence and author of Walking Home: the Life and Lessons of a City Builder.

http://greenbergconsultants. com/Resume.html. Retrieved March 30, 2013.

\section{ORGANIC GROWTH}

Like an organism, moving through cycles of transformation, successful communities must respond to growth in a dynamic manner. Aboriginal peoples have inhabited the vast landscape we call Canada for thousands of years. During that time they have developed a rich and diverse legacy of inhabitation that acknowledges and incorporates these cycles. But how does one retain these traditional values in the context of urban development?

As Kitigan Zibi Anishinabeg continues to grow and prosper, it is unavoidably coming to terms with these challenges. Across the world we are seeing the disintegration of the human-nature relationship with vanishing plant species, animal quantities and the lack of organically produced agriculture. This systematic failure across many major cities and communities around the world can perhaps be attributed to the mechanically prescribed notions which govern the development of modern human settlement in our present day. Influenced by great minds in urban development such as Jane Jacobs, city builder and urban theorist Ken Greenberg is a large proponent of organic growth models for city development. These models aim to shift from overly prevalent, mechanical ideologies, to a more biological framework. He states in his book, Walking Home: the Life and Lessons of a City Builder, "we must avoid trying to impose any arbitrary and static order on a phenomenon that is continually mutating and morphing with no fixed destination, though it grows and evolves as a result of important relationships that need to be kept in balance." 
SECTION 2.6

The People of the Garden River [Organic Growth]
Graphic illustrating the likelihood of choosing a mode of transportation based on the intended distance of travel. Graphics by author. 2012
Kitigan Zibi has been growing in a somewhat sporadic manner, building when and where land becomes available, or wherever seems like a suitable place to build at the time. They have maintained this method of expansion since the conception of the reserve in 1853. They are developing in a way that is quite organic and opposite to the mechanistic strategies of many suburban communities. Nevertheless, it is without a balance in structured strategies that the model is showing its weak points. The recent surge of ad hoc development can be partially attributed to the rapid increase in on-reserve population, forcing the community to build at an unusually quick pace. Because buildings on reserve are so scattered, they are noticing that it is becoming increasingly difficult to build and manage municipal infrastructure. For members living on the outskirts of the core, it is quite difficult to get around without some form of transportion. With most amenities sprinkled on or near highway 105 , residents must rely heavily on the use of automobiles to access these services, as well as visit friends and relatives. In the time of the electronic age, where everything is but an arm's reach away

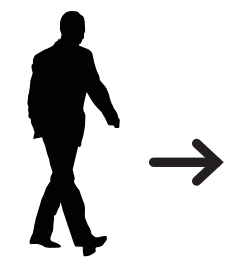

$<1 \mathrm{~km}$

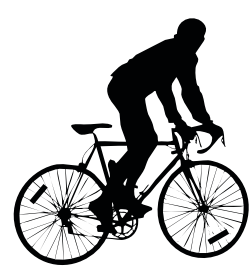

$<10 \mathrm{~km}$

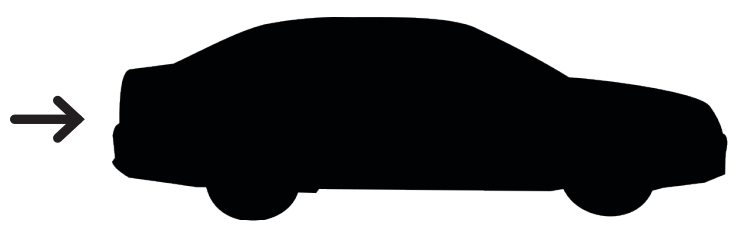

$>10 \mathrm{~km}$

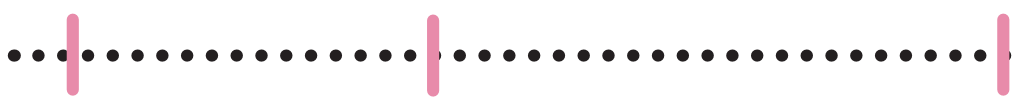


and social networks are digitized, it is becoming increasingly important to garner a physical connectedness within the community. Urban designer Jonathan Barnett once said, "It is not how dense you make it, but how you make it dense." 40 This statement is particularly interesting when placed in Kitigan Zibi's context. As only members of the band or ones associated directly by family ties can reside on reserve, the community's potential growth remains quite secure. Although theoretically stable, the recent surge in on-reserve population seems to indicate that growth can happen quite rapidly. Perhaps the growth signifies that community members living in other urban centers are migrating back to their home community as it continues to mature. If so, it is a positive sign that Kitigan Zibi's socio-economic conditions are developing rather successfully. If it continues at its current rate, the community will face numerous challenges on all developmental fronts. Community engagement will be the key to a more integrated and balanced approach to future development. 

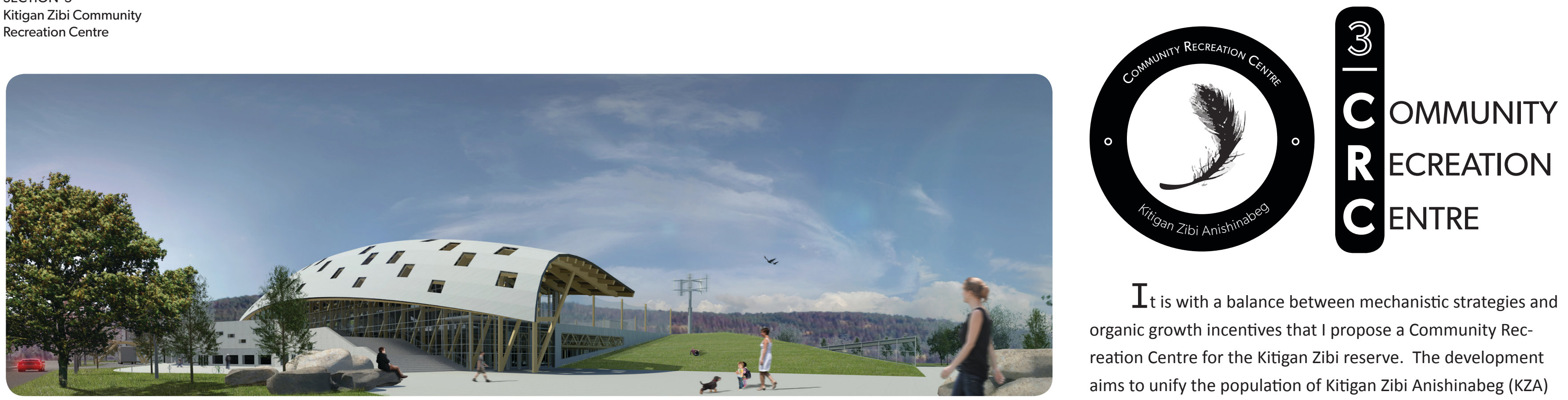

$I_{t}$ is with a balance between mechanistic strategies and organic growth incentives that I propose a Community Recreation Centre for the Kitigan Zibi reserve. The development aims to unify the population of Kitigan Zibi Anishinabeg (KZA) while inviting members from neighboring communities to

\section{ENURANCES}

39 Renderings of Commu-

40. Top image displaying view of the primary entrance at the east side of the complex. Bottom image displaying view of the community entrance from the Culy
parking lot.

Graphics and design

by author. 2013

\section{MAP}

KITIGAN Zibi ANISHINABEG

417 Map displaying area primary residential an commercial area. Aerial photographs.
Natrual Resources Canada. Taken in 2005 , recorded
digitally lune 2012

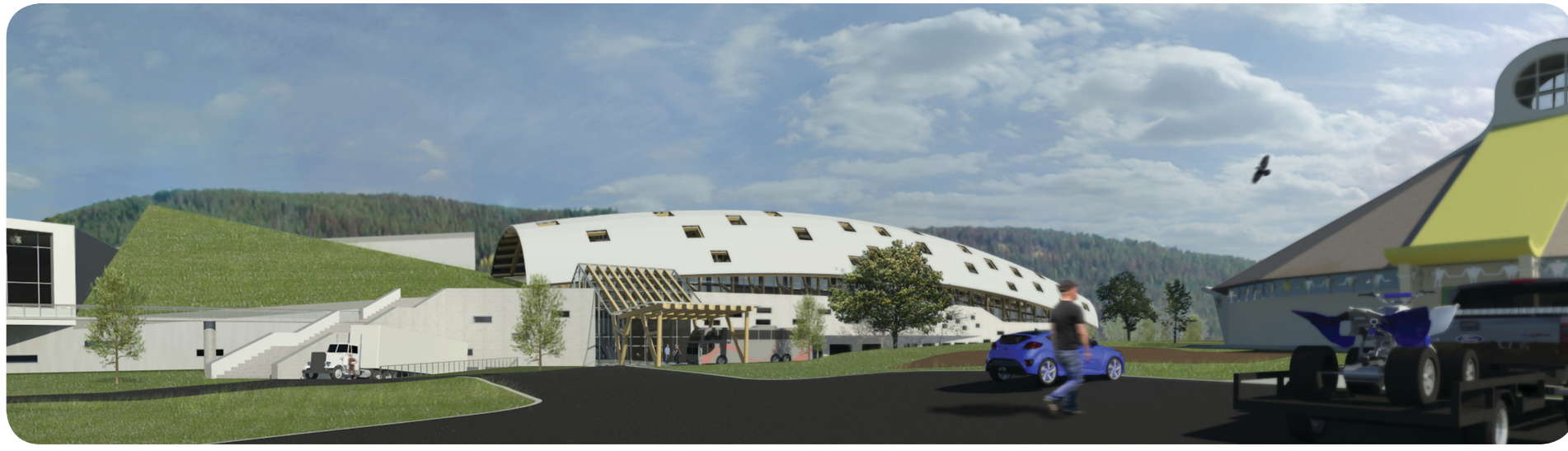

.

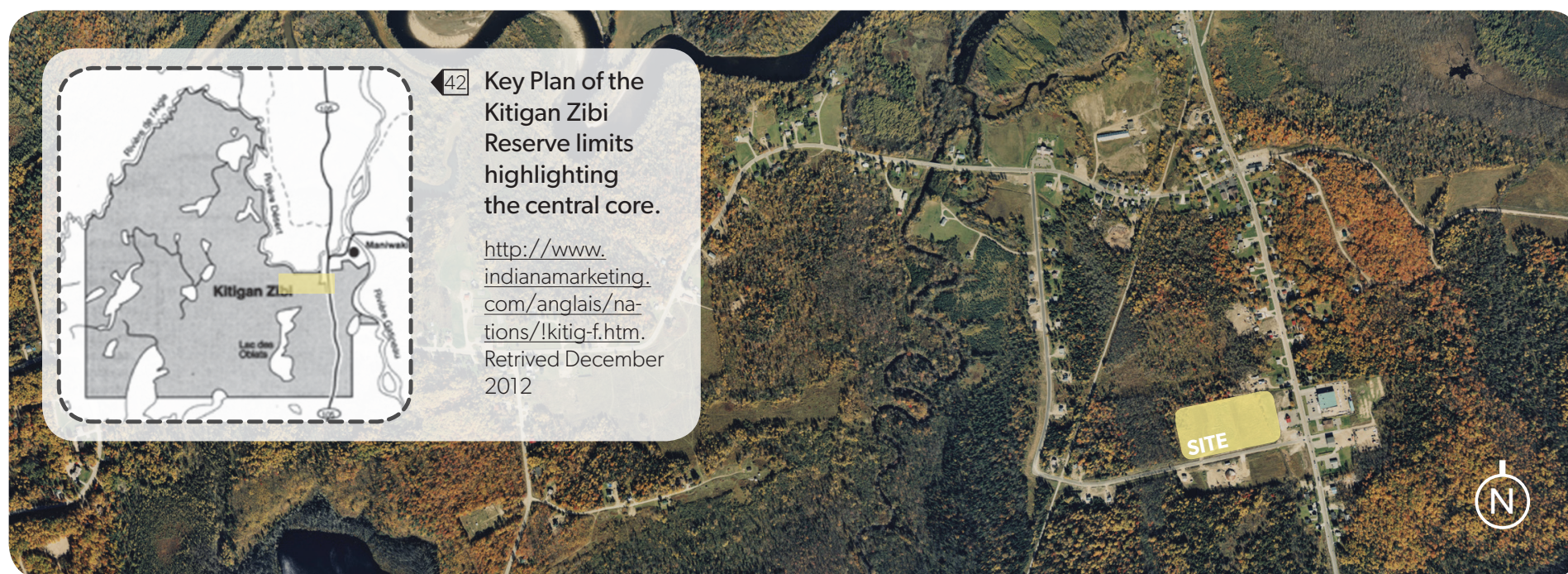

visit and enjoy a variety of activities on reserve. Strategically located across from the existing Cultural Center, the complex will provide the community of Kitigan Zibi Anishinabeg with a strong sense of place and identity, allowing its cultural and economic dynamics to flourish. The community recreation center will become the hub, fostering new connections and new beginnings for both members of the community and residents of neighboring locales in an organic manner. The centre unifies the existing Cultural Centre and the land it occupies into one large developed area, which is easily visible when driving into the core of the reserve. The development of the complex will occur in multiple phases, allowing the community to properly adjust and evolve along with the expansion of the project. The centre will offer amenities ranging from a full size ice pad, rooftop sports field, large indoor market place, street-front retail, library, Aboriginal museum, and programmable areas capable of hosting a variety of activities. The multiplicity of offerings aims to encourage growth in the core of the reserve, acting as an anchor point for future develop- 


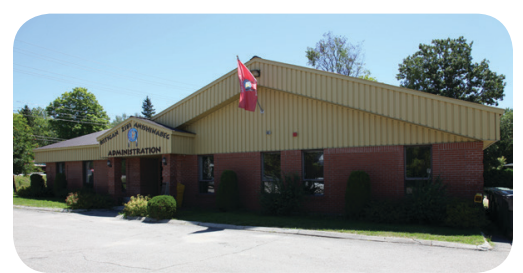

Photograph of the the Band Council Office proposed to host KZA's policing services following the completion of the Community Recreation Centre.

Photo: Bassam Daoud. Kitigan Zibi Anishinabeg. 2012

\section{Storm Water Runoff}

In the case of buildings, storm water runoff refers to water being shed away from the structure. Too much water run off can overload the capacity of municipal sewer systems. Green roofs help alleviate the strain on municipal infrastructure by retaining water. Water which is held on the roof is filtered, treated, and directed towards grey water cisterns which are used to flush toilets and water vegetation during dry periods. Water remaining in the soil is left to evaporate naturally, avoiding disruption sewer systems.

Wong, Michael. "Environmental Benifits of Green Roof." Hitchins Group Ltd., n.d. http://www.nea. gov.sg/cms/sei/PSS23slides.pdf (accessed March 31, 2013) ment. While Kitigan Zibi offers many unique and wonderful natural amenities and is beginning to offer and develop many of its public services, it currently has little to offer its residents in terms of urban livability. The new complex would act as a meeting place for community members, a place for chance encounters, somewhere to relax or engage in sporting activities, to sit and immerse themselves in the surrounding landscape, or even somewhere to enjoy a locally produced meal. Because the centre offers a wide variety of amenities, it has a little something for every member of the community.

Future growth phases of the development also include the relocation of the Band Council and adjacent construction administration office to a new, larger workplace providing the band with a more suitable and flexible work environment. The existing Band Council office building will be converted to host KZA's policing services. The move would allow the police department to acquire a building which offers additional office space, as well as a large garage. Additionally, it would provide the ability for the police department to expand their staff quite significantly, providing much needed jobs for the community requiring advanced training and education. The Band Council and construction administration will be located in the west side of the complex in an office block that will potentially host many other administrative and commercial functions. The relocation will allow the band to grow its current staff of 25 to roughly 50 employees, which will enhance the band's efficiency in managing the community's development into the future. 


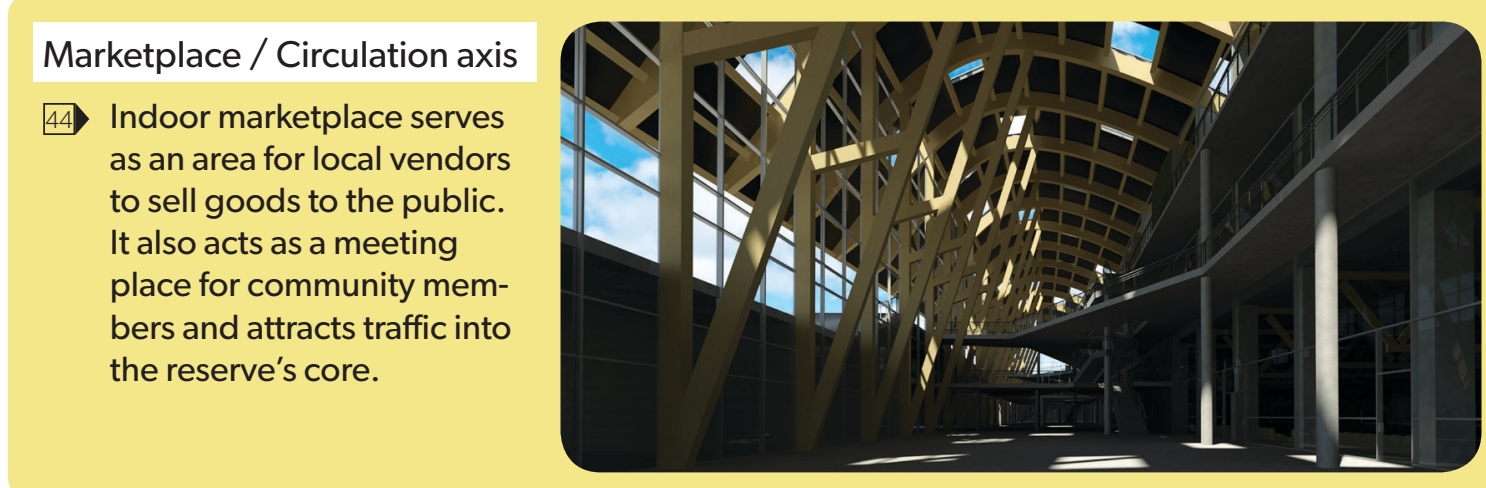

Ice rink + Rooftop sports field

45. Ice rink and rooftop playing field provide areas of recreation while maximizing land use. Both are highly accessible from numerous entry points and easily viewed from multiple areas creating a dynamic atmosphere throughout the centre.

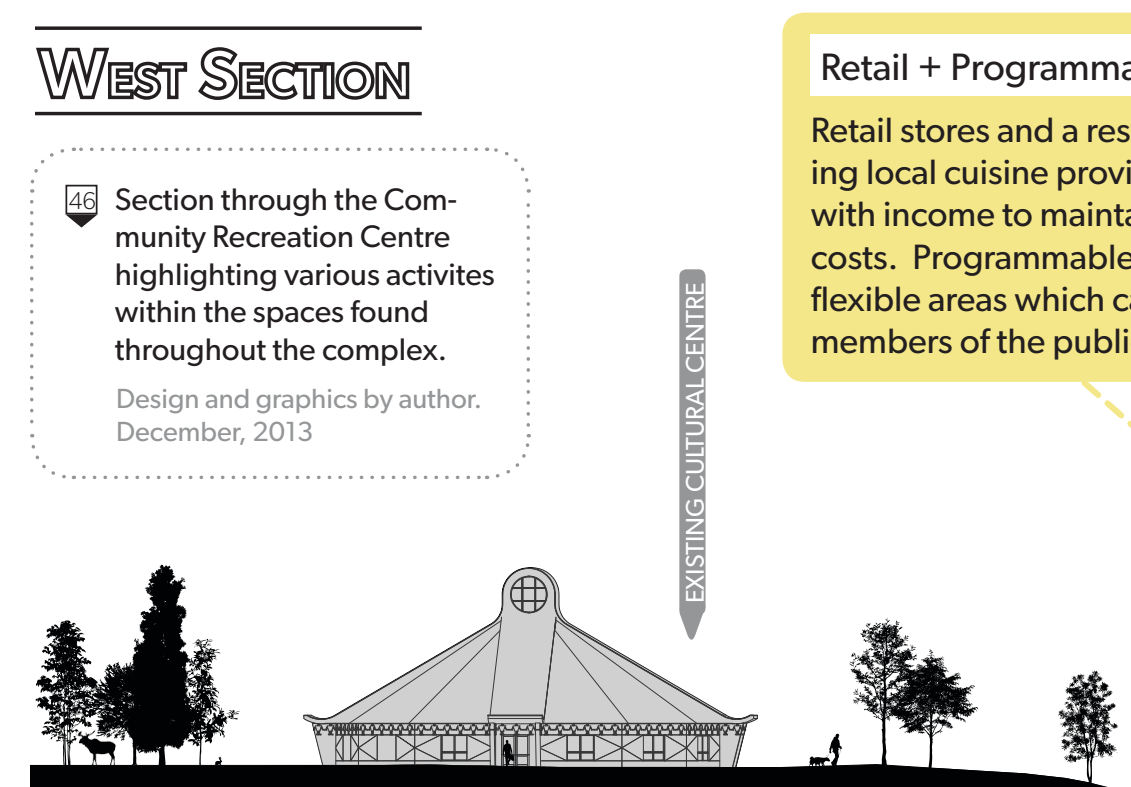

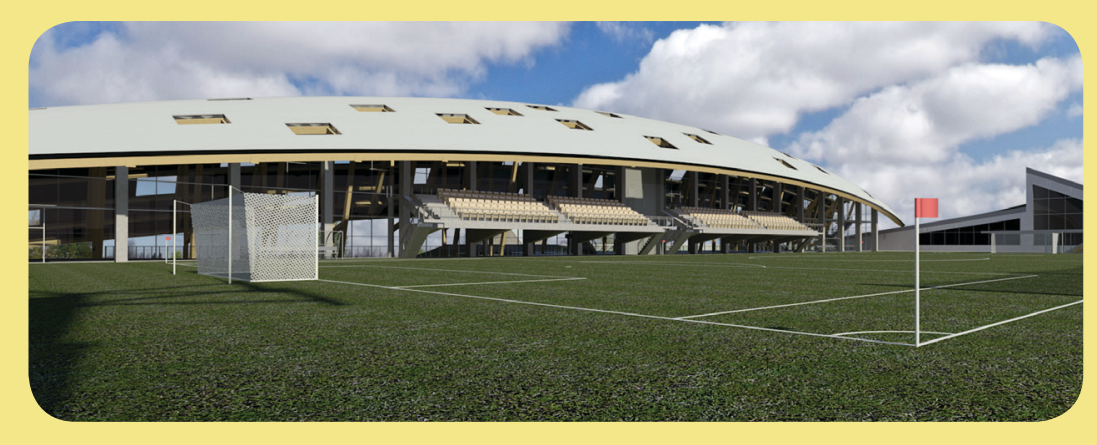

Below Grade Parking

Proposed is a parking structure which is sunken $4.5 \mathrm{~m}$ into the ground covered by a slope green rof. This provides access to the playing field while concealing automabing field allows the structure to blend into the landscape, borrowing views from the rolling hilltops in the distance. 


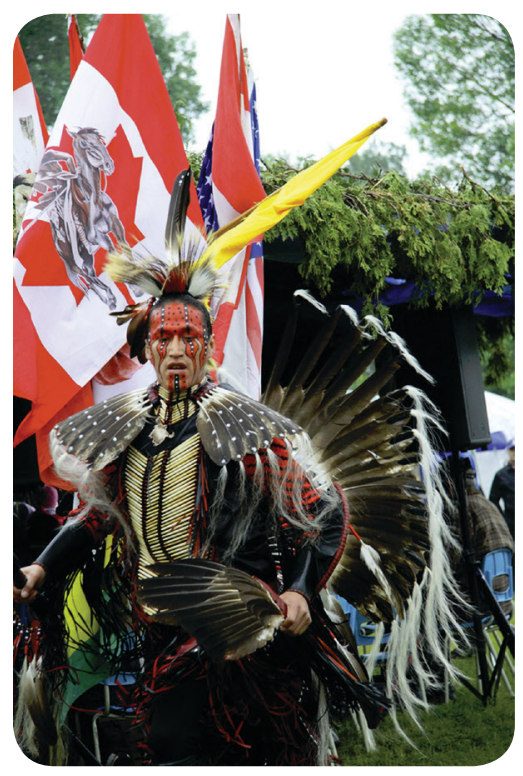

Photograph from the annual Kitigan Zibi Anishinabeg Powwow celebrations, in 2010.

Photo: Joey Hull. Kitigan Zibi Anishinabeg. June 05, 2010. http://www.flickr.com/photos/joeys_picz/4687382242/ in/photostream/. Retrieved March 31, 2013.
The recreational portion of the development is the most complicated functionally and is a key component in the development's capability to draw in members of the community. It is the core feature of the complex by which all other portions are organized and it is the most accessible module of the project, easily reached from any direction and at multiple levels. The recreation block hosts a full size ice pad, sunken 4.5 meters into the ground. This allows the arena to better manage energy levels and also maximizes its visibility and accessibility to other parts of the complex. The area hosts bleacher seating for 140 individuals, plus benches at gallery levels which can accommodate roughly 100 additional people. The arena is well serviced with a large garage door to the west side for maintenance vehicles, along with ample storage space for equipment. On the roof is a large outdoor sports field complete with raised bleachers which can seat 140 people. The athletic field doubles as an outdoor recreation space as well as a green roof controlling solar heat gain and water runoff. Minimizing the amount of solar gain into the arena allows for more efficient temperature moderation, particularly for the maintenance of a quality ice surface. The green roof will divert thousands of liters of water for from storm water systems and allow it to filter through into cisterns which will be served to flush lavatories, water vegetation, and for use on the ice pad. The playing field is specially designed to be a multi-purpose space and is itself an extension of the surrounding landscape, borrowing views from the surrounding hilltops. Along 


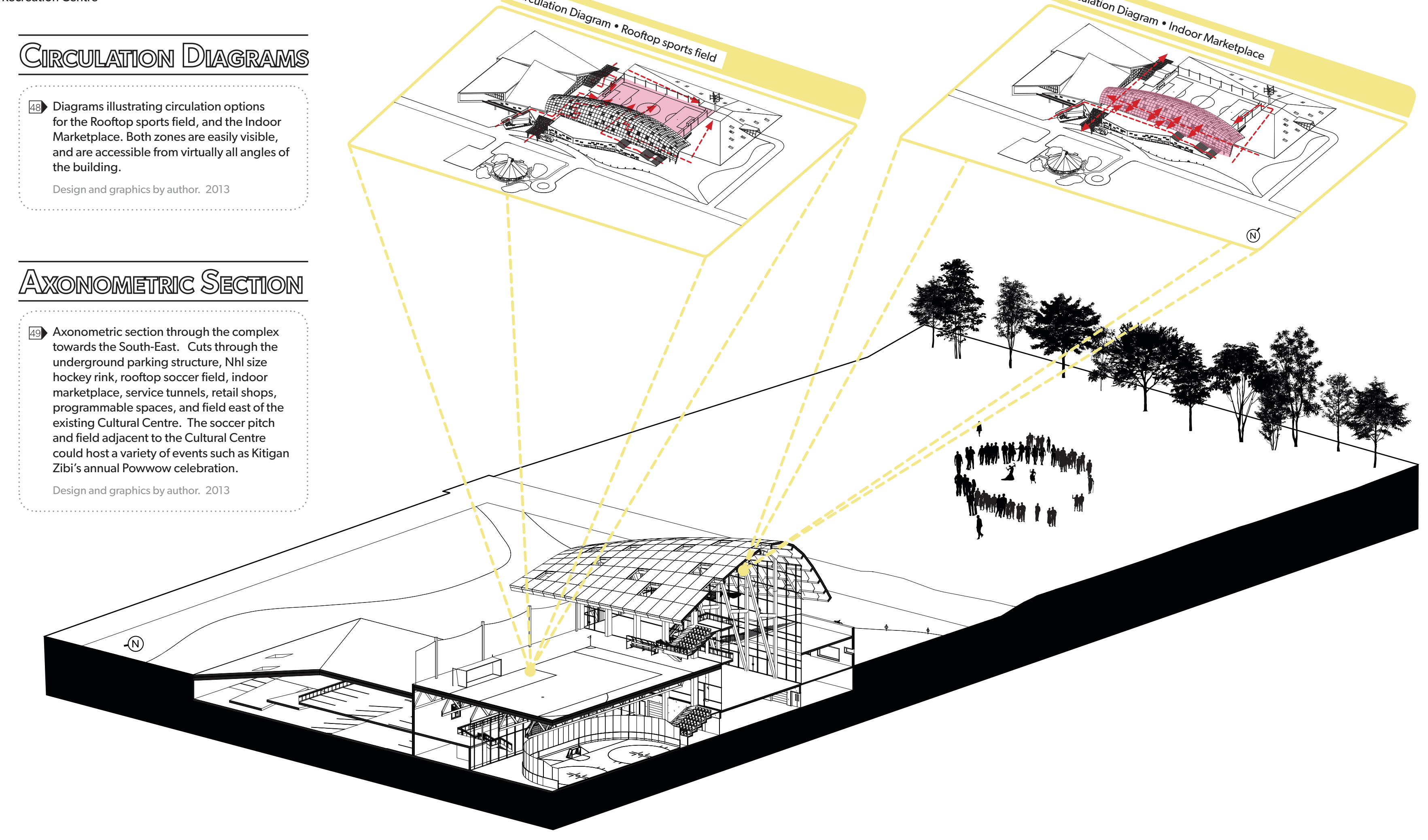




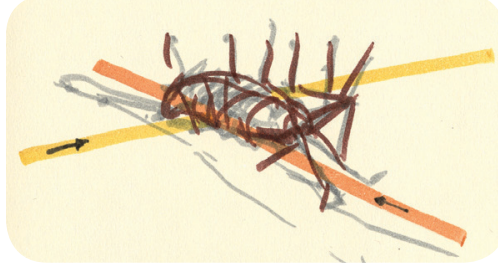

Preliminary sketch for circulation of the marketplace area.

Sketch by author. 2012 with the playing field, the large open green spaces surrounding the development as well as the rooftop playing field could be used to host events such as the annual Powwow or other seasonal outdoor events. Indoor events could be hosted in the arena facility and adjacent indoor marketplace. Potential expansion opportunities also include the possibility of an aquatics and fitness center to the north-west side of the complex. The expansion would further diversify the offerings the centre could bring to community members, promoting an active lifestyle and strengthening the socio-cultural dynamics on reserve.

The feasibility of this complex relies on the ability of its diverse programmatic functions to garner revenue. At grade, near the primary access road, will be locations for new local business opportunities. All commercial locations come equipped with their own storage space directly below grade, which are all easily serviced by the shipping and receiving area located at street side, adjacent to the office module. The shipping area also services the arena, allowing the movability and storage of equipment needed for maintenance as well as for performances and trade shows. Local business ventures such as KZA's ever expanding maple syrup enterprise will now have a platform to distribute and sell their goods to the general public. Also at grade will be the first and only museum in Canada to feature renowned Canadian Aboriginal Peoples, such as famous artists, athletes, or political figures. The museum will also host monthly exhibitions all focused on promoting Canadian Aboriginal culture 


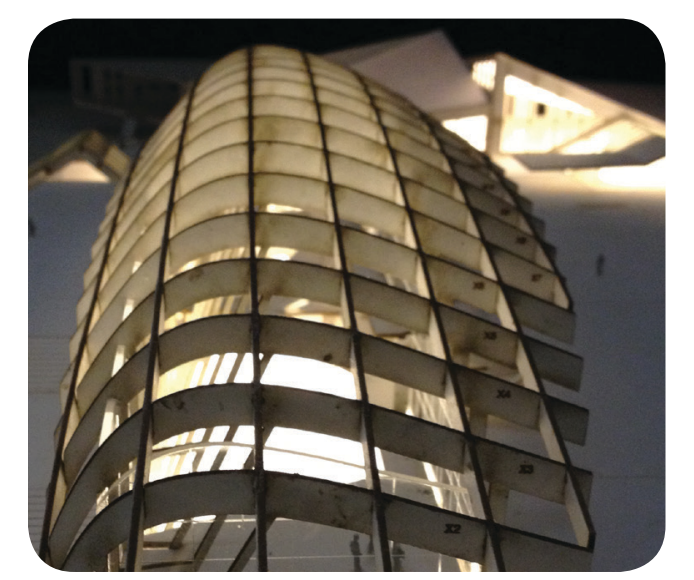

(57) View of structural system for Indoor Marketplace

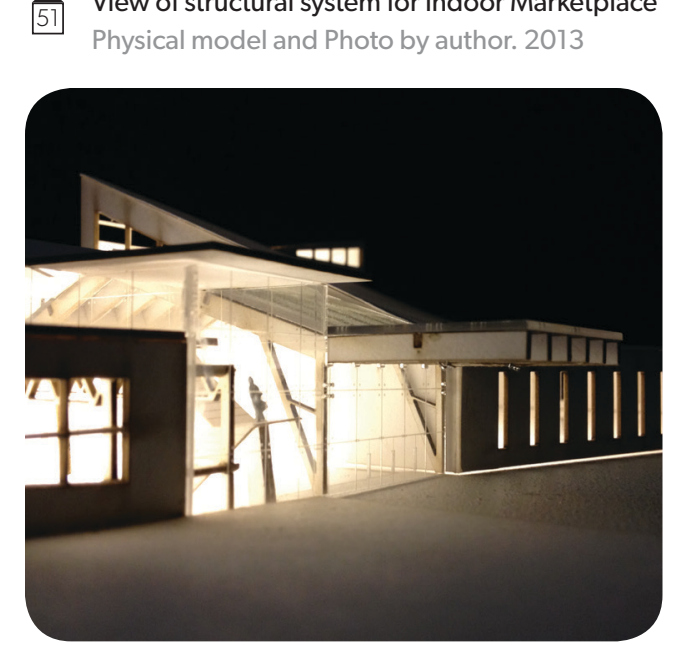

(55) View of North Entrance.

by author. 2013

56 View of Rooftop Sports Field looking west.
Physical model and Photo by author. 2013

52. View of primary entrance located on the east side of the complex.

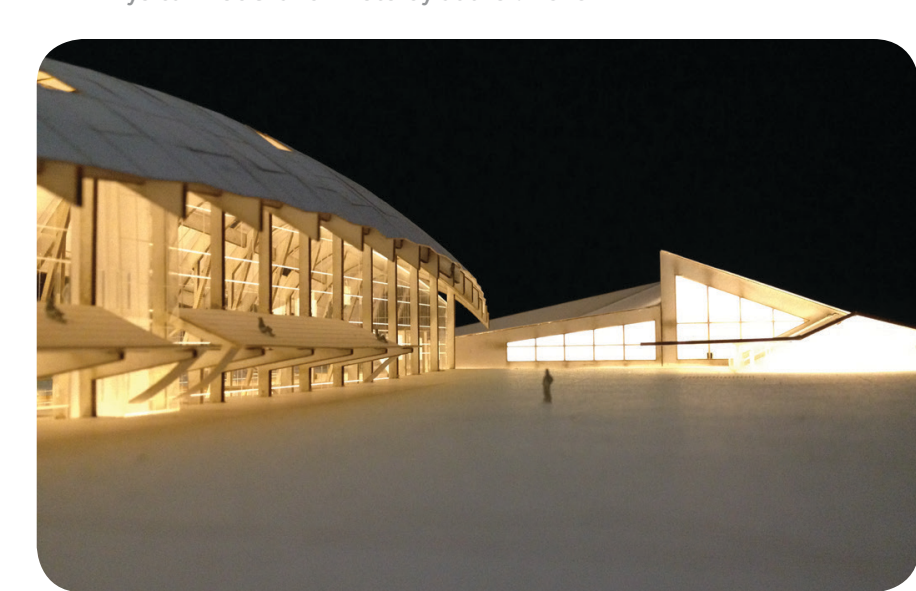

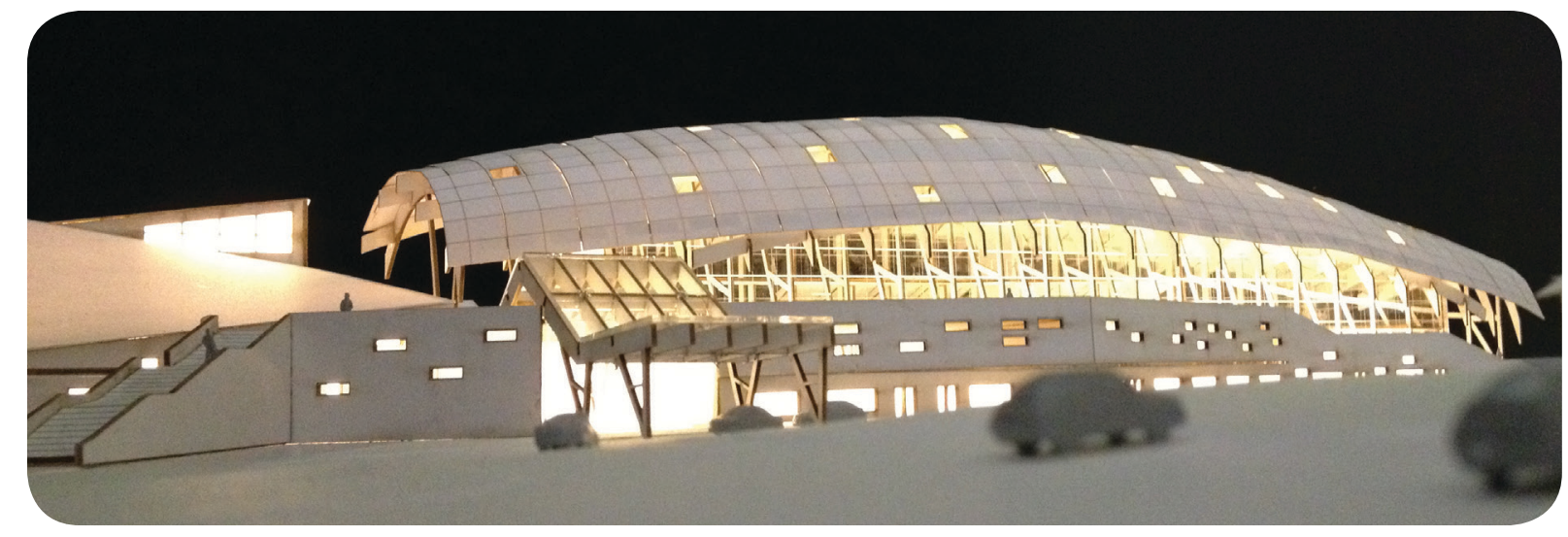

57. View of Community Recreation Centre, from Cultural Centre parking lot.

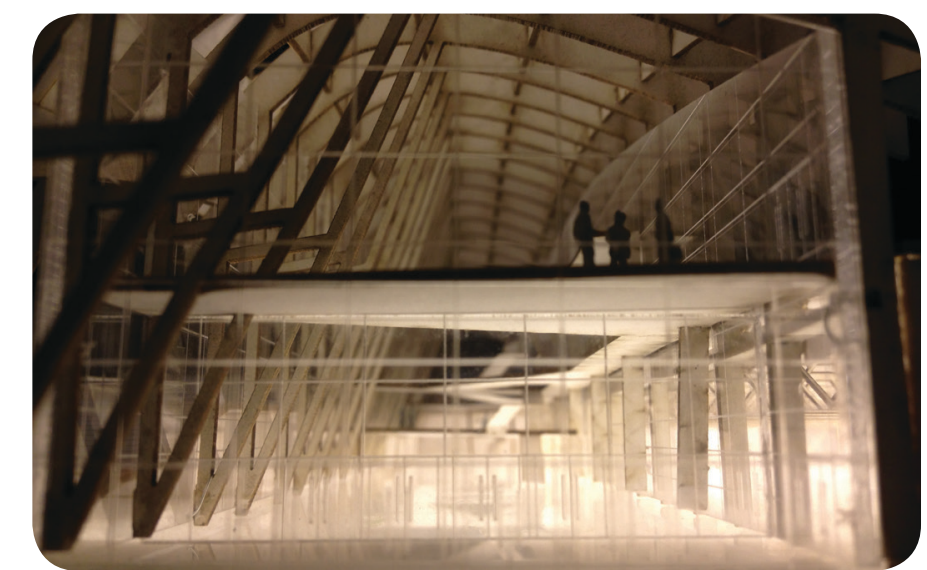

V3. View from East Entrance looking into Indoor Marketplace.

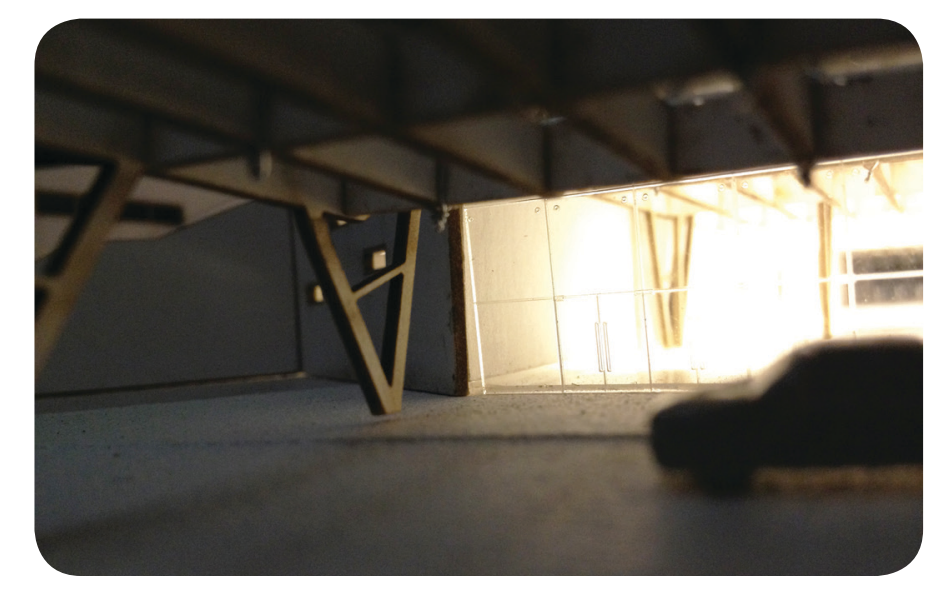

54 View from West Entrance, across from existing Cultural Centre

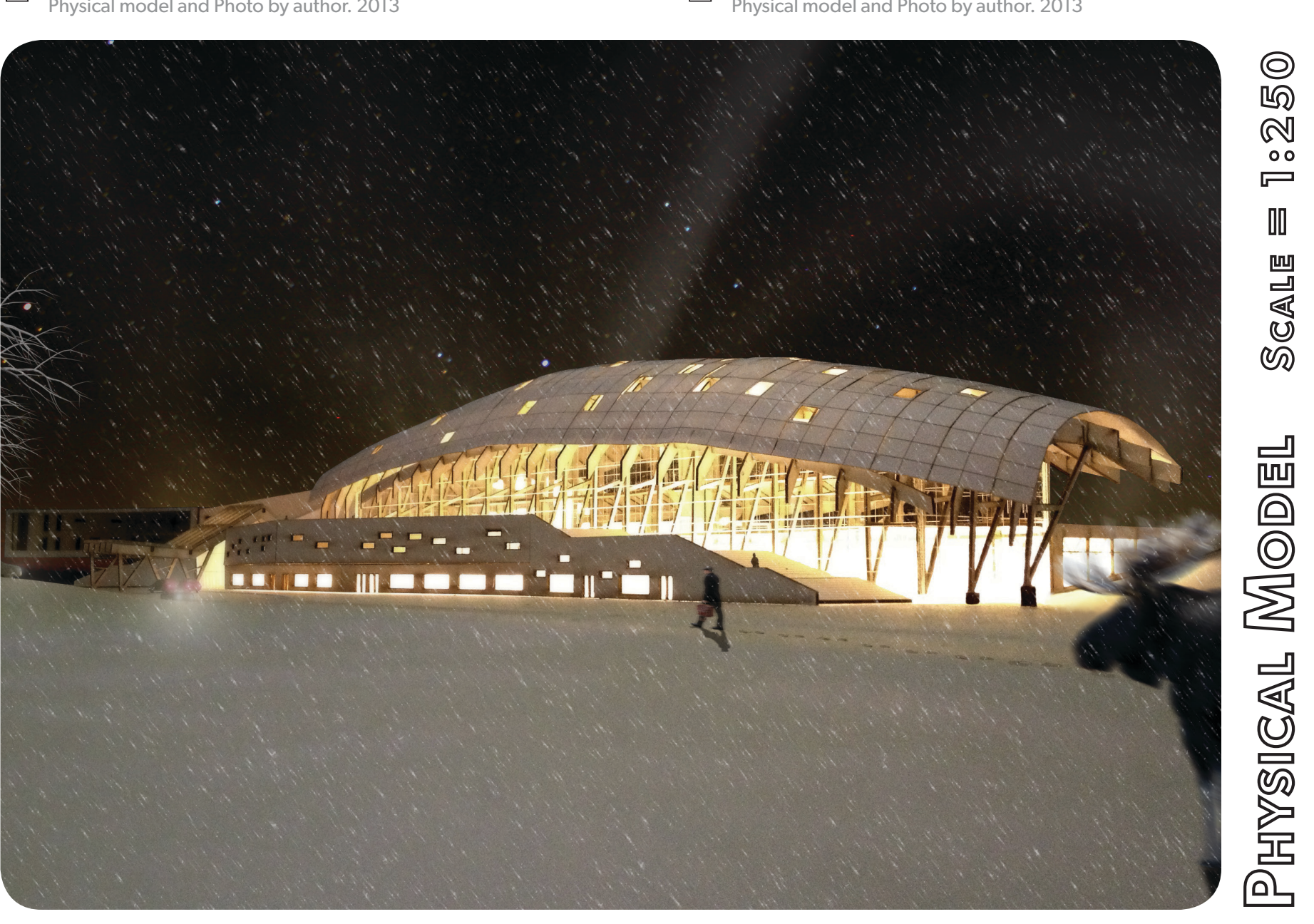

58 View of East Entrance, from Cultural Centre field, rendered to highlight evening conditions.
Physical model and Photo by author. 2013

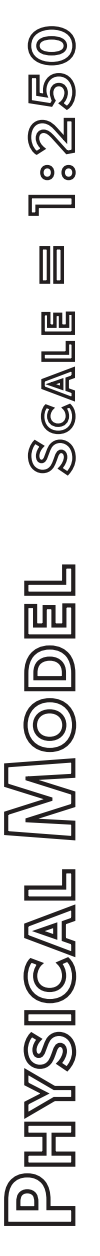


SECTION 3

Kitigan Zibi Community

Recreation Centre

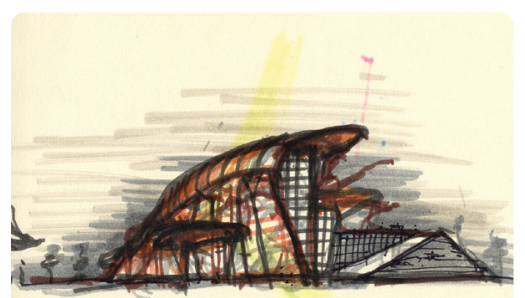

Preliminary sketch of east entrance showing sunken arena and rooftop sports field with ramped access.

Sketch by author. 2012 and the wide range of talents present amongst First Nations peoples. Due to the diverse offering of the centre, it is envisioned to be a high traffic zone within the community, which in turn supports both the commercial and recreational aspects of the project. The development would also incentivize members of neighboring communities to frequent the KZA, providing an external source of revenue for the community. The ability for the complex to host large scale events creates unique opportunities for the community to generate external financial interest and fuel tourism ventures on reserve. The complex will promote future growth on reserve, encouraging commercial and residential opportunities in the core of the community. The project aims to not only strengthen economic development, but also enrich the collective culture of Kitigan Zibi Anishinabeg. By providing a unique venue which will service the needs of the community, the complex will also act as model from which other First Nations communities can draw inspiration. 
FUTUIRE DEVIELOPRAENVIU

60) Schematic depictions of future development in the core of the community illustrating new roadways as well as
commercial and residential growth over a 30 year period.

New residential development

New commercial development New roads

Graphics and design by author. 2013

Fostering Growth

Located just off the primary axis of the community, the proposed

of the community, the proposed
site offers an ideal setting for a

development of this nature. The

community recreation centre will

provide the economic influx needed

to fuel growth over the next 30

years. The development will ser

to encourage members of the

community to reside closer to the

core of the reserve, alleviating the

effects of sprawl and maintaining a

sustainable model for infrastructural

growth. Strategic grouping of

complementary programmatic

functions creates a dynamic
environment providing visitors with

a wide range of activities, further

strengthening it's feasibility to
influence development in the core.

influence development in the core.

The centre will act as an anchor

point, a cultural and economic

mind, body and spirit.

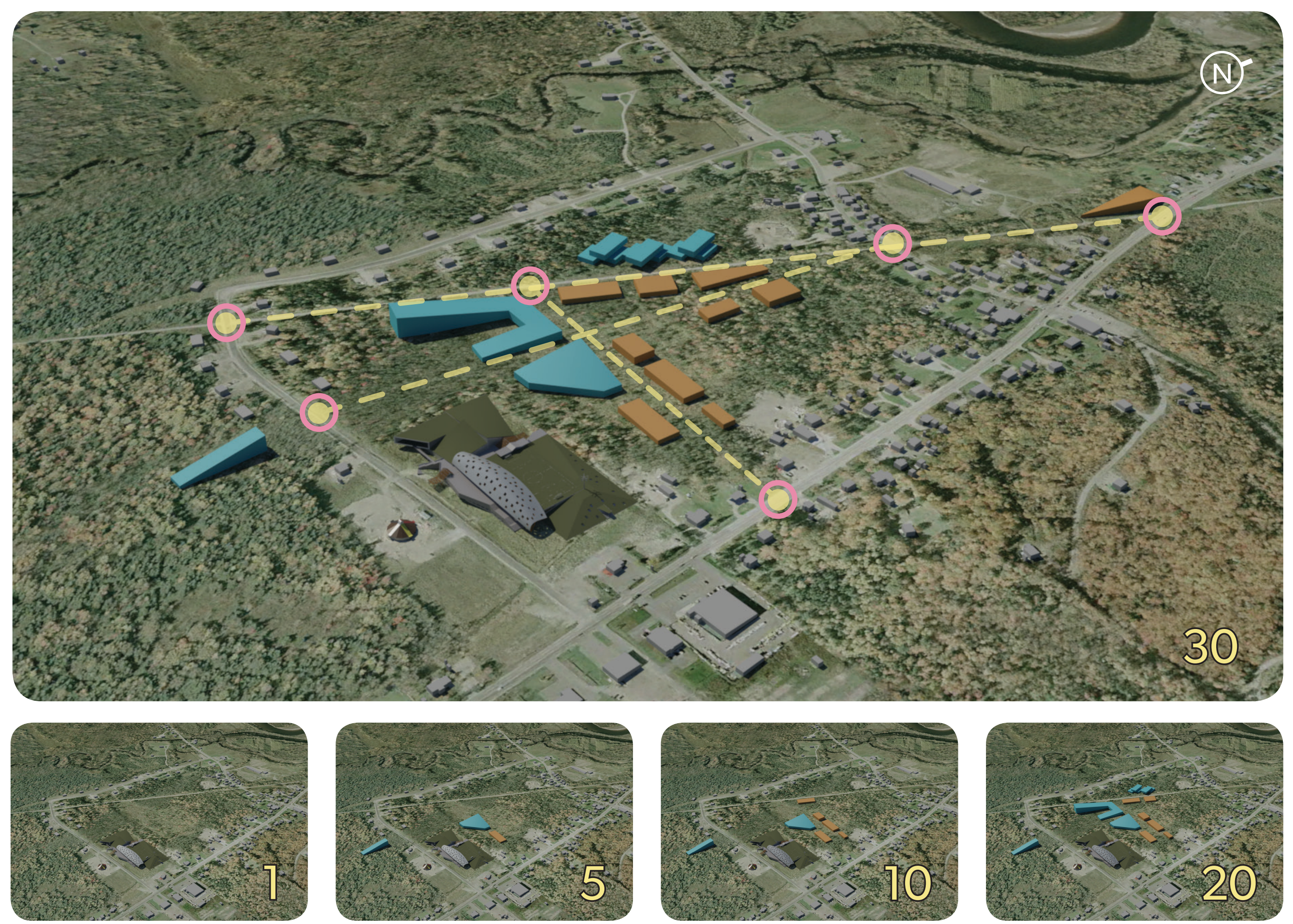


4 Banding

TOGETHER 


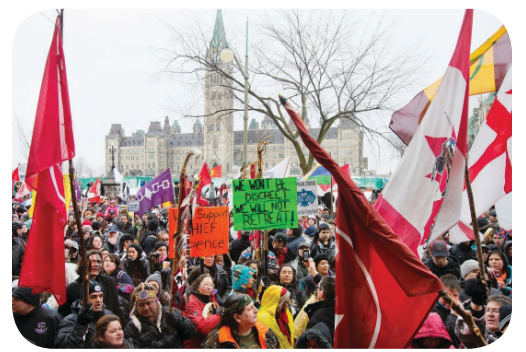

Photograph of Idle No More participants on Parliament Hill during a Janurary 11, 2013 demonstration.

http://www.ottawacitizen.com/ news/ottawa/Aboriginal+leaders+ldle+More+protests+Ottawa+include/7823711/story.html. Retrieved on April 1, 2013

\section{BANDING TOGETHER}

The rapport between First Nations peoples and colonized Canada has a long history of conflict and hardships. Aboriginal peoples have maintained a reciprocal relationship with the land they inhabited long before colonizers shifted the delicate equilibrium. It is not until in recent history that the mutual human-nature relationship has been tarnished and their cultural well beings placed at risk. European colonizers have created a landscape far removed from the one traditionally familiar to Aboriginal heritage. There has been a dilution in their cultural and architectural fabric from which they have depended on to survive for generations upon generations. Canada prides itself on multiculturalism and acceptance of all cultures, yet the government has an incredibly tarnished history of transgressions to the First Peoples of this land. The future presents an opportunity for all Canadians to unite in celebration of multiculturalism, and to embrace the various Aboriginal cultures that span to all corners of the country.

Architecture exists as a wonderful tool to help remediate the issues plaguing many Aboriginal communities across the nation. It is through a reciprocal dialogue between architects and First Nations that solutions can be uncovered, and by which architecture becomes a curative entity. Renowned architect Douglas Cardinal once said, "The architect really has a wonderful opportunity of bringing other people's visions into reality, but in order to do that you really have to walk in their 
shoes. You have to be humble and be open to criticism and regard your project as an opportunity for people's input so it can evolve to suit them. You don't bring answers to a community. The answers are already in the community." ${ }^{\prime 1}$ These inspiring words stem from a lifelong journey through which Douglas Cardinal has honed and shaped the landscapes of many communities and has greatly improved the lives of First Nations peoples throughout the country.

The architectural solutions proposed for the community of Kitigan Zibi Anishinabeg suggest approaches to better adapt to their current conditions. The off-grid housing scheme aims to mitigate their growth issues in the short term, providing members with an ecologically sustainable dwelling model. The Community Recreation Centre looks to improve on-reserve dynamics with long term goals of strengthening the core, by encouraging community members to frequent the central area of the reserve. The primary issue plaguing Kitigan Zibi's development into the future is the Certificate of Possession system, as it completely limits the Band's ability to develop prime land. The vast majority of CP land at KZA remains undeveloped, and since there is no associated cost to owning the property (not taxable), owners of the plots have no reason sell. The increase in traffic to the core should hopefully incentivise those occupying $\mathrm{CP}$ land to develop their plots into something that will benefit the community. Members could also enter into partnerships with the Band, allowing them to either share the land or become equal business 
partners in commercial/residential ventures. Both projects make use of natural wood products, which could be sustainably harvested on-reserve and manufactured at a nearby mill. Utilizing wood as a primary building material could revitalize the lumber industry in the area, while creating jobs in the local construction sector. Since wood can be harvested on reserve at a low cost to the Band, it also provides and economically viable building solution, while drastically reducing the carbon footprint of each design proposal.

The relationship that has been forged with the community of Kitigan Zibi Anishinabeg has provided me with knowledge that has directly informed the proposals for both housing opportunities and the community recreation centre. Maintaining a strong community dialogue has been essential to delivering an architecture that can both respond to the needs of Kitigan Zibi, and provide them with a unique tool which can encourage future development in the core of the reserve. The importance of tailoring the architecture for the specific needs of the community will establish a base from which Kitigan Zibi can grow and prosper along with their unique cultural traditions. 
I would like to thank my thesis advisor Steve Fai for the advice and guidance throughout this process. I would also like to thank Larry Hately, Mark Macguigan and Rob Wood, for all of your technical counsel. Your time and expertise was essential in bringing this project to fruition.

The material presented in this thesis was made possible through a steady dialogue with Chief Gilbert Whiteduck and general contractor Marcel Brascoupé. The direct involvement and enthusiasm of the community of Kitigan Zibi Anishinabeg has allowed this work to achieve its full potential. Thank you for welcoming me into your wonderful community. I am truly grateful to have had the opportunity to work with such an inspiring group of people.

To friends from near and far, I couldn't have reached this point without your support.

Finally, my parents Norm and Lise, my brothers Patrick and Mathieu, my grandmother Rita, godparents Lino and Jennifer Morandin and as well as my long time girlfriend Monika for all of their continued love and encouragement. This journey would not have been possible without all of you there every step of the way. Love you all. 


\section{BIBILOGRAPHY}

Alcantara, Christopher. "INDIVIDUAL PROPERTY RIGHTS ON CANADIAN INDIAN RESERVES: THE HISTORICAL EMERGENCE AND JURISPRUDENCE OF CERTIFICATES OF POSSESSION." n.d.

Attawapiskat First Nation. Canadian Buisness Ethics Research Network. n.d.

-. Architecture and the Canadian Fabric. Ed. Rhodri Windsor Liscombe. Vancouver, BC: UBC Press, 2011.

-. Networked Cultures: Parallel Architecture and the Politics of Space. Ed. Peter Mortenbock and Helge Mooshammer. Rotterdam: NAi Publishers, 2008.

—. The Algonquins. Ed. Daniel Clément. Hull: Canadian Museum of Civilization, 1996.

-. "Broadacre City: A New Community Plan." Architectural Record (1935).

Varis Bokalders, Maria Block. The Whole Building Handbook. Trans. Miles Goldstick

Boddy, Trevor. The Architecture of Douglas Cardinal . Edmonton: NeWest Press, 1989.

Brewster, Mike. "Frank Lloyd Wright: America's Architect." Bloomberg Buisness Week 27 July 2004.

Brown, Rachel. Attiwapiskat Fundraiser Alan Neal. 28 November 2011.

Cardinal, Douglas. Indigenous Human Library Stephane Bolduc. Ottawa, 29 January 2013.

Cook, Maria. "Douglas Cardinal says a life surrounded by just concrete and people can be devastating." The Ottawa Citizen 25 February 2012.

Correspondent, Citizen. " \$25,000 flood control study approved for Maniwaki area." The Ottawa Citizen 30 June 1986.

Frampton, Kenneth. Towards a Critical Regionalism: Six points for an Architecture of Resistance. Ed. Hal Foster. Seattle: Bay Press, 1983.

Gilbert Whiteduck, Marcel Brascouper. Tribal Tectonics. Stephane Bolduc. 11122012.

Greenberg, Ken. Walking Home: the Life and Lessons of a City Builder. Toronto: Random House, 2011.

Hessel, Peter. The Algonkin Nation. Arnprior: Kichesippi Books, 1993. 
Hudson Stewart, Toofan Ostovar. "An Investigation Into Sustainable Water Management System for New Sub." 2010.

Kent Mckay, Sharfraaz Kaba. "First Steps." Canadian Architect October 2012.

Maier, Hanna. "Long-Life Concrete Pavements in Europe and Canada." 2007.

Maracle, Brian. Our Native Land. Canadian Broadcasting Corporation. 29091984.

Peter Nabokov, Robert Easton. Native American Architecture. New York: Oxford University Press, 1989.

Pulla, Siomonn. "Antorpological advocacy?: Frank Speck and the mapping of Aboriginal territoriality in eastern Canada, 1900-1950." Ottawa: Department of Sociology and Anthropology, Carleton University, 18 April 2006.

Roumeliotis, loanna. "Aboriginal land claim includes Toronto, suburbs." News Report. 2003.

Speck, Frank Gouldsmith. A Northern Algonquian Source Book. Ed. Edward S. Rogers. 1985.

Stastna, Kazi. "Shacks and slop pails: infrastructure crisis on native reserves." News Report. 2011.

Susane Kredentser. London: Earthscan, 2010.

Whiteduck, Gilbert. "Evidence of meeting \#22 for Aboriginal Affairs and Northern Development in the 41st Parliament, 1st Session." Aboriginal Affairs and Northern Development . Parliament of Canada, 2012.

Wong, Michael. "Environmental Benifits of Green Roof." Hitchins Group Ltd., n.d.

Wright, Frank Lloyd. The Living City. New York: Horizon Press, 1958.

ZAFERATOS, Nicholas CHRISTOS. Planning for Native American Indian Reservations. Carfax Publishing, 2004. 
1. Frank Gouldsmith Speck. A Northern Algonquian Source Book. Ed. Edward S. Rogers. 1985. p.290-295

2. Daniel, Clement. The Algonquins. P.78-82

3. 8th Fire: At the Crossroads. The Canadian Broadcasting Corporation. 2011

4. Maria Cook. Douglas Cardinal says a life surrounded by just concrete and people can be devastating. Ottawa Citizen. http://www.ottawacitizen.com/health/ need+life+around+architect/6210666/story.html. accessed 2012/11/12

5. Douglas Cardinal. Indigenous Human Library Stephane Bolduc. Ottawa, 29 January 2013.

6. Statistics Canada. Census of Population. Release no. 5. http://www12.statcan.ca/census-recensement/2006/rt-td/ap-pa-eng.cfm. 2008

7. Aboriginal Affairs and Northern Development Canada. http://www.aadnc-aandc.gc.ca/ eng/1100100014265/1100100014269. 2006

8. Aboriginal Affairs and Northern Development Canada. http://www.aadnc-aandc.gc.ca/ eng/1100100013791/1100100013795. 2006

9. Ioanna Roumeliotis. Aboriginal Land Claims includes Toronto, suburbs. The Canadian Brocasting Corporation. http://www.cbc.ca/news/canada/story/2003/06/17/landclaim_030617.html

10. Kazi Stastna. Shacks and slop pails: infrastructure crisis on native reserves. The Canadian Broadcasting Corporation. http://www.cbc.ca/news/canada/story/2011/11/24/f-first-nations-infrastructure.html. 2011/12/08

11. Kent Mckay, Sharfraaz Kaba. "First Steps." Canadian Architect October 2012. p.27-30

12. Rachel Brown - True North Aid, The Canadian Broadcasting Corporation, Radio One. http://www.cbc.ca/player/Radio/Local+Shows/Ontario/All+in+a+Day/ ID/2171878159/?page=16\&sort=MostPopular

13. Aboriginal Affairs and Northern Development Canada. Kitigan Zibi Anishinabeg Profile. http://www.aadnc-aandc.gc.ca/Mobile/Nations/profile_kitiganzibi-eng.html. Accessed February 15, 2013

14. National Resources Canada http://clss.nrcan.gc.ca/data-donnees/publications/indlanhisque-hisfonterindque/kitigan_zibi_ang.pdf

15. Jaques Frenette. The Algonquins. Ed. Daniel Clément. Hull: Canadian Museum of Civilization, 1996. p.75

16. Hessel, Peter. The Algonkin Nation. Arnprior: Kichesippi Books, 1993. p.91-100

17. Jaques Frenette. The Algonquins. Ed. Daniel Clément. Hull: Canadian Museum of Civilization, 1996. p.79-80

18. Frank Gouldsmith Speck. A Northern Algonquian Source Book. Ed. Edward S. Rogers. 1985. p.290-295

19. Siomonn Pulla. "Antorpological advocacy?: Frank Speck and the mapping of Aboriginal territoriality in easternCanada, 1900-1950." Ottawa: Department of Sociology and 
Anthropology, Carleton University, n.d. p.9-11

20. Ibid. p.25

21. Ibid. p. 28

22. Frank Lloyd Wright. The Living City. New York: Horizon Press, 1958. p.138-139

23. Ibid. p.147-148

24. unknown. "Broadacre City: A New Community Plan." Architectural Record (1935).

25. Gilbert Whiteduck, Marcel Brascouper. Tribal Tectonics Stephane Bolduc. 11122012.

26. Alcantara, Christopher. "INDIVIDUAL PROPERTY RIGHTS ON CANADIAN INDIAN RESERVES: THE HISTORICAL EMERGENCE AND JURISPRUDENCE OF CERTIFICATES OF POSSESSION." n.d. p.393

27. Jaques Frenette. The Algonquins. Ed. Daniel Clément. Hull: Canadian Museum of Civilization, 1996. p.75

28. unknown. Awazibi Maple Syrup. http://kzadmin.com/AwazibiProcess.aspx\#. Accessed, 2013/02/15

29. Aboriginal Affairs and Northern Development Canada. Kitigan Zibi Anishinabeg Profile. http://www.aadnc-aandc.gc.ca/Mobile/Nations/profile_kitiganzibi-eng.html. Accessed February 15, 2013

30. Statistics Canada. 2012. Maniwaki, Quebec (Code 2483065) and Quebec (Code 24) (table). Census Profile. 2011 Census. Statistics Canada Catalogue no. 98-316-XWE. Ottawa. Released October 24, 2012. http://www12.statcan.gc.ca/census-recensement/2011/ $\mathrm{dp}-\mathrm{pd} / \mathrm{prof} /$ index.cfm? Lang $=\mathrm{E}$

31. (accessed February 15, 2013)

32. Radon Measurement and Mitigation Project. Marcel Brascoupé. 1st Annual CARST Conference. Ottawa, Canada. http://www.carst.ca/assets/documents/KitiganZibiRadonProjectPresentation.pdf . April 27, 2012

33. Gilbert Whiteduck, Marcel Brascouper. Meeting, Tribal Tectonics. Stephane Bolduc. 2012/12/11.

34. Gilbert Whiteduck, Marcel Brascouper. Meeting, Tribal Tectonics. Stephane Bolduc. 2012/12/11.

35. Citizen Correspondent. " $\$ 25,000$ flood control study approved for Maniwaki area." The Ottawa Citizen 30 June 1986. p.B3

36. Ken Greenberg. Walking Home: the Life and Lessons of a City Builder. Toronto: Random House, 2011. p.78-79

37. Statistics Canada. 2012. Focus on Geography Series, 2011 Census. Statistics Canada Catalogue no. 98-310-XWE2011004. Ottawa, Ontario. Analytical products, 2011 Census. Last updated October 24, 2012.

38. Hanna Maier. Long-Life Concrete Pavements in Europe and Canada (Report). Federal Highway Administration. October 9, 2007. Retrieved February 02, 2012.

39. Greenberg, Ken. Walking Home: the Life and Lessons of a City Builder. Toronto: Random House, 2011. p.88

40. Ibid. p.89

41. Maria Cook. "Douglas Cardinal says a life surrounded by just concrete and people can be devastating." The Ottawa Citizen . 25 February 2012. 
Graphic representation of traditional land occupation.

by author. 2013/03/26

Photo displaying use of the Gatineau

2 River for logging purposes. These practices lead to the erosion of traditional First Nations territories.

Samuel J. Jarvis. Logs on the Gatineau River. Library and Archives of Canada. http://collectionscanada.gc.ca/pam archives/index. php?fuseaction=genitem.displayEcopies\&lang=eng\&rec_ $\underline{n b r=3372610 \& r e c \_n b r}$ _ list $=3623597,337260$ -

9,3321579,3321599,3392889,3321573,3321593,3372610,3321580\&title $=$ [Logs + on +the + Gatineau + River \%2C+P.Q.]. +\&ecopy=a025083\&ba ck_url=\%28\%29. captured between 1900-1939. retrieved 2013/03/26

Photo depicting South-West view of the Cree Cultural Institute,

o.3 located in Oujé-Bougoumou, QC. Building designed by architect Douglas Cardinal.

Cree Cultural Institute. http://www. creeculturalinstitute. Oujé-Bougoumou, QC. ca/wp-content/gallery/ media-en/X0C4071.jpg . retrieved 2012/12/18

\section{(4) MP}

p.3 OUJÉ-BOUGOUMOU VILLAGE

Oujé-Bougoumou Tourism. http:// www.ouje.ca/downloads/ouje-map-business-directory.pdf. retrieved 2013/03/26

Early design sketch of an indoor marketplace, following a conversap.5 tion with members of the Kitigan Zibi community.

Sketch by author. 2013/01/10

\section{D.6 MAP Canada - First Nations}

Graphic representation of Aborignal population accross Canada.

Graphics by author. 2013/03/26

Photo depicting third world living conditions on the Attawapiskat First

p.8 Nations reserve. A torn Canadian flag flapping in the background, serves a stark reminder that the Canadian government has done little to aid the situation.

Attawapiskat, ON. http://o.canada. com/2012/12/02/neighbouring-reserve-to-attawapiskat-declares-fuel-housing-emergency/. retrieved 2012/12/18

Photo depicting a home in disrepair, on the Attawapiskat First p.9 Nations Reserve.

Attawapiskat, ON. http://www. torontosun.com/2011/12/21/unblasts-wrong-minister-over-attawapiskat. retrieved 2012/12/18

\section{回 $\mathbb{M} \mathbb{A}$}

\section{p.10 Kitigan ZiBI ANISHINABeg}

RESERVE AREA: 45750 acres

Satellite imagery denoting the territorial limits of the Kitigan Zibi Anishinabeg First Nations Reserve.

Graphics by author. 2013/03/26

Kitigan Zibi Anishinabeg and Maniwaki, Google Earth (version 7.0.3.8542), Google Inc. (2012), Available at: kh.google.com Retrived 2012/05/12
10 MAP Algonguin Migration

Formation of Kitigan Zibi Anishinabeg

Map outlining the travel made by the Algonquin population, later forming the Kitigan Zibi Anishinabeg reserve.

https://maps.google.com/ maps? $\|=45.45,-74 \&$ spn $=0.25,0.25$ $\& t=h \& q=45.45,-74$

11 Graphic representation of wild p.15 farming. It can be described as a conservational practice, where Aboriginal families would ration the amount of animals to be hunted, in order to ensure stability to the overal health of the ecosystem they depended on to survive.

graphic by author. 2013/01/07

12 Drafted hand drawing of an exterior 12 plan view depicting a quadruple

p.17 housing cluster as part of the Broadacre city proposal.

Frank Lloyd Wright. The Living City. New York: Horizon Press, 1958. p.151

Rendered hand drawing of an aerial view depicting scattered high rises,

p.17 farm land, higways, and numerous circular helicopters flying above Broadacre City's countryside.

Frank Lloyd Wright. The Living City. New York: Horizon Press, 1958. p.181

14. Physical Model of Stadium and

p.17 Circus for county fair as well as other various programmic functions.

Frank Lloyd Wright. The Living City. New York: Horizon Press, 1958. p.181

Graphic representation the current growth model for the Kit-

p.18 igan Zibi Anishinabeg community, where every new home built is allotted 1 acre of land. graphic by author. 2013/01/07 


\section{四AP \\ ${ }^{0.22}$ Kitigan ZiBi Anishinabeg \\ HOUSING \\ Aerial Photograph at intersection of Kikinamage Mikan and Bitobi road, displaying sparse living conditions on reserve. \\ Aerial photograph. Natrual \\ Resources Canada. Taken in 2005 , recorded digitally June 2012 \\ 17 M.25 \\ KITIGAN ZIBI ANISHINABEG \\ CONSERVATION AREA}

Detailed map outlining the natural features within the conservation area on reserve.

M.C Foret inc: Gestion et inter vention forestiere. Prepared by Marcelle Falardeau

Photo of the town of Maniwaki. Taken near the border between p.26 Kitigan Zibi and Maniwaki, towards the north on highway 105.

http://commons.wikimedia.org/ wiki/File:Maniwaki_QC.JPG\#file captured in 2008

Photo of the Kitigan Zibi Reserve, towards the north at the corner of p.26 highway 105 and Makwa Mikan road.

https://maps.google.

$\mathrm{ca} / \mathrm{maps} \mathrm{q}=$ maniwaki\&oe $=$ utf-8\&aq $=$ t\&rls=org mozilla:en-US:official\&client=firefox-a\&um $=1 \& i e=U T F-8 \& h l=e n \& s$ $\mathrm{a}=\mathrm{N} \& \mathrm{tab}=\mathrm{wl}$. captured in 2012

p. 28

Cultural Centre [54 Makwa Mikan Road]

Photo: Bassam Daoud. Kitigan Zibi Anishinabeg. 2012
Band Council Office [1 Paganakomin Mikan Road]

Photo: Bassam Daoud. Kitigan Zibi Anishinabeg. 2012

Wazoson Childcare Center p. 28 [38 Paganakomin Mikan Road] Photo: Bassam Daoud. Kitigan Zibi Anishinabeg. 2012

Kikinamadinan Elementary \& High School [41 Kikinamage Mikan Road.]

Photo: Bassam Daoud. Kitigan Zibi Anishinabeg. 2012

24 Mino Bimadiziwin Good Life Cenp. 28 tre [Paganakomin Mikan Road]

Photo: Bassam Daoud. Kitigan Zibi Anishinabeg. 2012

Kiweda Group Home [41 p. 28 Kikinamage Mikan Road.

Photo: Bassam Daoud. Kitigan Zibi Anishinabeg. 2012

Mokasige Immersion School p. 28 [37 Kikinamage Mikan Road.]

Photo: Bassam Daoud. Kitigan Zibi Anishinabeg. 2012

\section{MAP}

\section{KITIGAN ZiBI ANISHINABEG}

CENTRAL CORE

Map displaying area of density on reserve; primary residential and commercial area.

Aerial photographs. Natrual Resources Canada. Taken in 2005, recorded digitally June 2012

28 Key Plan of the Kitigan Zibi Reserve limits highlighting the central core.

http://www. indianamarketing. com/anglais/nations/!kitig-f. htm. Retrived December 2012
Photo of a traditional Algonquian p.31 domed Wigwam using elm bark.

Peter Nabokov, Robert Easton Native American Architecture. New York: Oxford University Press, 1989. Capured in 1866 p.62

Photo of a 2 storey home with base30 ment, located at 71 Bitobi Road,

p.32 in the Kitigan Zibi Anishinabeg reserve.

https://ssl.panoramio.com/ photo_explorer\#view=photo\&position=3\&with_photo_ id $=76648993 \&$ order $=$ date_desc\&user $=6987044$. Posted on August 6, 2012. Retrieved on March 30, 2013

North elevation of proposal for the Kitigan Zibi Anishinabeg

p.32 community.

Design and graphics by author. December, 2012

2 Perspective view of housing proposal for the Kitigan Zib Anishinabeg community.

Design and graphics by author. December, 2012

East Elevation of housing proposal for the Kitigan Zibi Anishinabeg community.

Design and graphics by author. December, 2012

34 North Elevation of housing proposal highlighting sustainable features.

Design and graphics by author. December, 2012

Aerial photograph of Ottawa's p.38 downtown core.

Tom Alfoldi. http://www.flickr.com/ photos/tta/4065296617/sizes/o/ in/photostream/. Retrieved on March 30,2013 


\section{SECTION E}

List of Figures

Aerial photograph of Toronto's Lake Ontario waterfront, showing multiple nodes of density in the distance.

http://forum.skyscraperpage.com/ showthread.php?t=170593. Retrieved on March 30, 2013

37 Photograph of the MacdonaldCartier Freeway (highway 401), at p.38 a section containing 16 lanes.

Justin Cozart. http://www.flickr. $\mathrm{com} /$ photos/fatguyinalittlecoat/6352225678/. November 14, 2011. Retrieved February 2, 2013

38 Graphic illustrating the likelihood of choosing a mode of transportation based on the intended distance of travel.

Graphics by author.

December, 2012

\section{ENTRANAES}

Renderings of Community Recreation Centre. Top image displaying view of the primary entrance at the east side of the complex. Bottom image displaying view of the community entrance from the Cultural Centre parking lot.

Graphics and design by author. 2013

\section{${ }_{0.45} \mathbb{M} \mathbb{A} P$ \\ Kitigan ZiBI ANISHINABEG \\ CENTRAL CORE}

Map displaying area of density on reserve; primary residential and commercial area.

Aerial photographs. Natrual Resources Canada. Taken in 2005, recorded digitally June 2012
42 Key Plan of the Kitigan Zibi

p.42 Reserve limits highlighting the central core.

http://www.indianamarketing. com/anglais/nations/!kitig-f.htm. Retrived December 2012

43 Photograph of the the Band

43 Council Office proposed to host

p.46 KZA's policing services following the completion of the Community Recreation Centre.

Photo: Bassam Daoud. Kitigan Zibi Anishinabeg. 2012

44 Indoor marketplace serves

44 as an area for local vendors

p.47 to sell goods to the public. It also acts as a meeting place for community members and attracts traffic into the reserve's core.

Graphic and design by author. 2013

45 Ice rink and rooftop playing 45 field provide areas of recreation p.47 while maximizing land use. Both are highly accessible from numerous entry points and easily viewed from multiple areas creating a dynamic atmosphere throughout the centre.

Graphic and design by author. 2013

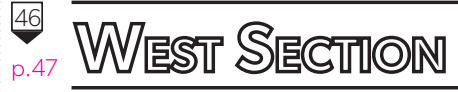

Section through the Community Recreation Centre highlighting various activites within the spaces found throughout the complex.

Design and graphics by author. December, 2013
Photograph from the annual Kitigan Zibi Anishinabeg Powwow p.48 celebrations, in 2010 .

Photo: Joey Hull. Kitigan Zibi Anishinabeg. June 05, 2010. http://www.flickr.com/photos/joeys_picz/4687382242/ in/photostream/. Retrieved March 31, 2013

48 C.49RULATION DIAGRAMS

p.49 Diagrams illustrating circulation options for the Rooftop sports field, and the Indoor Marketplace. Both zones are easily visible, and are accessible from virtually all angles of the building.

Design and graphics by author. 2013

\section{AXXONOMETRIC SECIION} p.49

Axonometric section through the complex towards the South-East. Cuts through the underground parking structure, Nhl size hockey rink, rooftop soccer field, indoor marketplace, service tunnels, retail shops, programmable spaces, and field east of the existing Cultural Centre. The soccer pitch and field adjacent to the Cultural Centre could host a variety of events such as Kitigan Zibi's annual Powwow celebration.

Design and graphics by author. 2013

Preliminary sketch for circulation of the marketplace area.

Sketch by author. 2012 


\section{SECTION E}

List of Figures

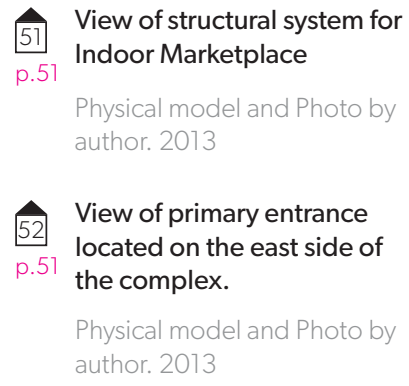

View from East Entrance looking into Indoor Marketplace.

Physical model and Photo by author. 2013

54 View from West Entrance, across from existing Cultural Centre

Physical model and Photo by author. 2013

55 View of North Entrance.

5.51 Physical model and Photo by author. 2013

56 View of Rooftop Sports Field looking west.

Physical model and Photo by author. 2013
57 View of Community Recreation Centre,from Cultural Centre parking lot.

Physical model and Photo by author. 2013

58 View of East Entrance, from

58 Cultural Centre field, rendered to highlight evening conditions.

Physical model and Photo by author. 2013

59 Preliminary sketch of east entrance showing sunken

p.51 arena and rooftop sports field with ramped access.

Sketch by author. 2012
60

P.53 $\frac{\text { FUTURR DEVELOPMENT }}{\text { Schematic depictions of future }}$ development in the core of the community illustrating new roadways as well as commercial and residential growth over a 30 year period.

Graphics and design by author. 2013

6] Photograph of Idle No More participants on Parliament

p. 55 Hill during a Janurary 11, 2013 demonstration.

http://www.ottawacitizen. com/news/ottawa/Aboriginal+leaders+ldle+More+protests+Ottawa+include/7823711/story.html. Retrieved on April 1, 2013 


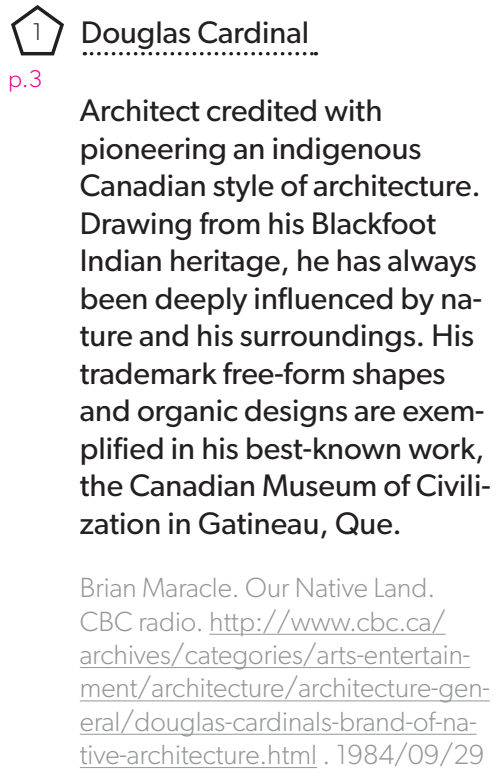

\section{2) Chief Terrance Paul}

p.9 Terry Paul is the Chief of the Membertou, a position he has held since 1984. During that time, Paul has guided his community and administration into one of the most open and efficient native communities in the country.

http://www.membertou.ca/ chief_coucil.asp. Accessed 2013/03/30
3) Frank Gouldsmith Speck
(1881-1950)

American anthropologist specializing in the study of Algonquian and Iroquoian peoples of Canada and the United States. As a strong proponent and advocate of Aboriginal rights, Speck's work provided a basis from which representations of Aboriginal territoriality could be developed. His work also took a stand against racism in specific governmental policies of assimilation directed towards First Nations people. In certain cases this would involve direct confrontation with government officials.

Siomonn Pulla. "Antorpological advocacy?: Frank Speck and the mapping of Aboriginal territoriality in eastern Canada, 1900-1950." Ottawa: Department of Sociology and Anthropology, Carleton University, 18 April 2006. p.219-220

\section{Frank Lloyd Wright
p.16 (1867-1959)}

American architect of international fame. A large proponent of buildings at harmony with people at their surroundings, he developped a philosophy called Organic Architecture. He is best know for his design of the Falling Water house, located in Pensylvania.

Mike Brewster. "Frank Lloyd Wright: America's Architect." Bloomberg Buisness Week. http://www.businessweek. com/stories/2004-07-27/ frank-Iloyd-wright-americas-architect 27 July 2004

\section{Gilbert Whiteduck \\ Chief of the Kitigan Zibi Anishinabeg band since 2008. A well received and respected leader in the com- munity. Is a strong avocate of Aboriginal rights and claims to territory never seeded to government. Amongst others, land disputes (some dating back to the 1800's) amounting to over 500 acres of land with bordering town of Maniwaki remain in the}

Whiteduck, Gilbert. "Evidence of meeting \#22 for Aboriginal Affairs and Northern Development in the 41st Parliament, 7st Session." Aboriginal Affairs and Northern Development. Parliament of Canada, 2012. http://www. parl. gc.ca/HousePublications/Publication. aspx?Docld=5366598\&Language $=E \& M o d e=1$

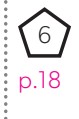

Marcel Brascoupé

General construction contractor for the Kitigan Zibi Anishinabeg Band and vice president of the Canadian Association of Radon Scientists and technologists. He is responsible for much of the building activity on reserve as well as the mitigation of radon gas issues.

Canadian Association of Radon Scientists and technologists. http:// www.carst.ca/en/directors. html 


\section{SECTION E}

List of People

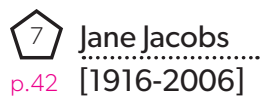

Urban activist and writer best known for her 1961 treatise, The Death and Life of Great American Cities. She advocated extensively for new community based approaches and philosophies, emphasizing the importance local neighborhoods. She approached cities as living ecosystems, suggesting over time that every portion of a city functions together as dynamic organism evolving according to how people interact with each aspect.

http://www.pps.org/reference/jiacobs-2/. Retrieved March 30, 2013.

(8) Ken Greenberg

p.42 An architect, urban designer and theorist based out of Toronto, Ontario. He has been a pivotal figure on public and private projects throughout North America and Europe for over 30 years. His projects focus mainly on the rejuvenation of city waterfronts and neighborhoods. He is the recipient of the 2010 American Institute of Architects Thomas Jefferson Award for public design excellence and author of Walking Home: the Life and Lessons of a City Builder.

http://greenbergconsultants com/Resume.html. Retrieved March 30, 2013. 


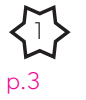

Oujé-Bougoumou

Small Aboriginal community in Northern Québec with an unfortunate history of abuse, neglect and dispossession, from mining and forestry companies, as well as governments at both the provincial and federal levels. Living conditions on-reserve were often compared some of the worst amongst third world countries. After generations of wrongdoings, in May 1992 , the community finally received assistance, securing funds from the federal government to build the Oujé-Bougoumou Cree Village. This development consisted of a complete rebuild and redesign of the entire community.

In The Past. http://www. ouje $\mathrm{ca} /$ content/our-story/history. php . retrieved 2013/03/27
\{2\} Attawapiskat

p. 8

First Nations community located in Northern Ontario. The traditional territory of the band extends far past the boundaries of the reserve. The band has approximately 2800 members with roughly 1500 living on reserve. Due to its remote location, the community is accessible only by train, and via a winter ice road between the months of January and March. Living conditions on reserve are quite poor, and have been considered on par with many third world nations. Government assistance to mitigate issues of poverty continues to be limited.

Attawapiskat First Nation. Canadian Buisness Ethics Research Network. http://www.cbern.ca/ research/projects/workspaces/ cura_project/case_studies/attawapiskat_first_nation/ 
List of Quotes

LIST OF QUOTES

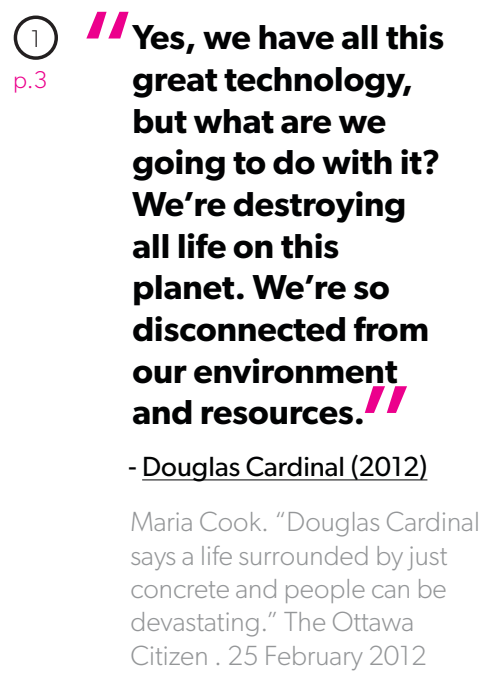

(2) I/So a "bank" would be only a well calculated responsibility, not of the individual but of the people! A non-political, non-profit institution in charge of medium of exchange - a medium having, in itself, no possible speculative value.

-Frank Lloyd Wright

Frank Lloyd Wright. The Living

City. New York: Horizon Press, 1958. p. 167 
List of Elaborations

\section{LIST OF ELABORATIONS}

\section{Radon Gas}

A radioactive gas which forms naturally through the breakdown of uranium in soil, rock and water. It can not be detected by the senses, but can be detected with the use of special instruments. Inhaling Radon deposits small particles into the lungs known to cause damage or death to cells. Radon gas is attributed to causing on average $16 \%$ of all lung cancer deaths.

Health Canada. http://www. hc-sc.gc.ca/ewh-semt/radiation/ radon/faq_fq-eng.php\#radon Modified on 2013-02-04

Canadian Mortgage and

p.29 Hoursing Corportation (CMHC)

Canada's national housing agency, established in 1946 as a governement owned opperation. The agency began by addressing the post-war housing situation following World War II, but has now grown into a major national institution. They provide research into housing technologies, policy and programs, mortgage loan insurance, as well as mortagebacked securities.

Canadian Mortgage and Hoursing Corportation. http:// www.cmhc-schl.gc.ca/en/ corp/about/. Retrieved 2013. 03-30
Urban Areas

Statistics Canada classifies urban areas to "have a population of at least 1,000 and no fewer than 400 persons per square kilometre. They include both census metropolitan areas and urban non-census metropolitan areas."

Statistics Canada. Definitions and notes. http://www12. statcan.gc.ca/census-recensement/2006/as-sa/97-558/

note-eng.cfm

(accessed March 30, 2013)

Rural Areas

Statistics Canada classifies rural areas to "include all territory lying outside of urban areas, excluding Indian reserves as defined above. They include remote and wilderness areas, agricultural lands, as well as small towns, villages and other populated places with a population of less than 1,000 and a density of less than 400 persons per square kilometre."

Statistics Canada. Definitions and notes. http://wwwl2.statcan.gc. $\mathrm{ca} /$ census-recensement/2006/ as-sa/97-558/note-eng.cfm (accessed March 30, 2013)

\section{Storm Water Runoff}

p. 46

I the case of buildings, storm water run off refers to water being shed away from the structure. Too much water run off can overload the capacity of municipal sewer systems. Green roofs help alevitate the strain on municipal infrastructure by retaining water. Water which is held on the roof is filtered, treated, and directed towards grey water cisterns which are used to flush toilets and water vegetation during dry periods. Water remaning in the soil is left to evaporate naturally, avoiding disruption sewer systems.

Wong, Michael. "Environmental Benifits of Green Roof." Hitchins Group Ltd., n.d. http://www.nea. gov.sg/cms/sei/PSS23slides.pdf (accessed March 31, 2013) 